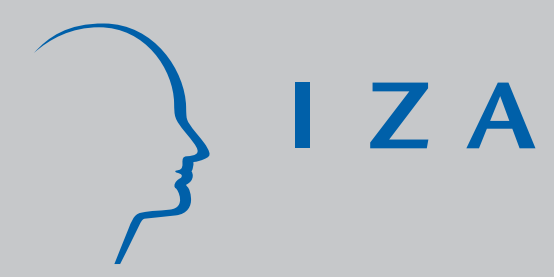

IZA DP No. 3936

Undocumented Worker Employment and Firm Survival

J. David Brown J ulie L. Hotchkiss Myriam Quispe-Agnoli

J anuary 2009 


\title{
Undocumented Worker Employment and Firm Survival
}

\author{
J. David Brown \\ Heriot-Watt University and IZA \\ Julie L. Hotchkiss \\ Federal Reserve Bank of Atlanta \\ and Georgia State University \\ Myriam Quispe-Agnoli
Federal Reserve Bank of Atlanta
}

Discussion Paper No. 3936

January 2009

IZA

P.O. Box 7240

53072 Bonn

Germany

Phone: $+49-228-3894-0$

Fax: +49-228-3894-180

E-mail: iza@iza.org

\begin{abstract}
Any opinions expressed here are those of the author(s) and not those of IZA. Research published in this series may include views on policy, but the institute itself takes no institutional policy positions.

The Institute for the Study of Labor (IZA) in Bonn is a local and virtual international research center and a place of communication between science, politics and business. IZA is an independent nonprofit organization supported by Deutsche Post World Net. The center is associated with the University of Bonn and offers a stimulating research environment through its international network, workshops and conferences, data service, project support, research visits and doctoral program. IZA engages in (i) original and internationally competitive research in all fields of labor economics, (ii) development of policy concepts, and (iii) dissemination of research results and concepts to the interested public.
\end{abstract}

IZA Discussion Papers often represent preliminary work and are circulated to encourage discussion. Citation of such a paper should account for its provisional character. A revised version may be available directly from the author. 


\section{ABSTRACT}

\section{Undocumented Worker Employment and Firm Survival ${ }^{*}$}

Do firms employing undocumented workers have a competitive advantage? Using administrative data from the state of Georgia, this paper investigates the incidence of undocumented worker employment across firms and how it affects firm survival. Firms are found to engage in herding behavior, being more likely to employ undocumented workers if competitors do. Rivals' undocumented employment harms firms' ability to survive, while firms' own undocumented employment strongly enhances their survival prospects. This suggests that firms enjoy cost savings from employing lower-paid undocumented workers at wages less than their marginal revenue product. The herding behavior and competitive effects are found to be much weaker in geographically broad product markets, where firms have the option to shift labor-intensive production out of state or abroad.

JEL Classification: L1, J23, J61

Keywords: undocumented workers, firm dynamics, monopsony, immigration policy

Corresponding author:

J. David Brown

School of Management and Languages

Heriot-Watt University

Edinburgh EH14 4AS

United Kingdom

E-mail: J.D.Brown@hw.ac.uk

\footnotetext{
* The views expressed in this paper are those of the authors and do not necessarily reflect those of the Federal Reserve Bank of Atlanta or the Federal Reserve System. Valuable research assistance was provided by Nicole Baerg, Katharyn Rees, Navnita Sarma, and Menbere Shiferaw. The authors also benefited from consultations with Clark Burdick and Russell Hudson from the Social Security Administration and from discussions with participants at seminars at the Federal Reserve Bank of Atlanta, Oberlin College, and Heriot-Watt University. Additional helpful comments and suggestions were also received from Atanas Christev, Jacques Melitz, and Mark Schaffer.
} 


\section{Undocumented Worker Employment and Firm Survival}

\section{Introduction}

Firms may inherently wish to obey the law. But if breaking the law can give firms a competitive advantage, some may be tempted to do so. Using administrative data from the state of Georgia, Hotchkiss and Quispe-Agnoli (2008) find a significant wage differential between documented and undocumented workers. If this wage gap reflects more than productivity differences and costs from breaking the law, the employment of undocumented workers could reduce firm costs. We make use of the same Georgia administrative data to test whether employing undocumented workers actually gives firms a competitive advantage. ${ }^{1}$

The answer to this question has implications for immigration policy. If undocumented worker employment is found to provide a competitive advantage, then a reduction in the supply of undocumented workers (e.g., via tougher border and worksite enforcement) will raise production costs. The answer also has political implications. Understanding the mechanism driving the firm's decision process to employ undocumented workers will inform policy makers about potential opposition to successfully implementing proposed reforms and how those reforms might be structured to address concerns of employers.

There is a large literature on undocumented workers (see Hanson 2006 for a review), but almost no prior studies have investigated undocumented worker employment at the firm level. One exception is Morales (1983-1984), who conducts eight case studies of Los Angeles auto parts manufacturers. She finds that firms adapt to growing competition by employing undocumented workers, who are in plentiful supply in that area. The firms employing

\footnotetext{
${ }^{1}$ It has often been claimed in the immigration debate that firms employing undocumented workers have an advantage over their competitors, but this has never been empirically tested. See, for example, Subcommittee on Workforce Protections (2006, pp. 25-26) or Cave (2008).
} 
undocumented workers tend to be more labor intensive and face more variable demand (necessitating easily released labor). There is no previous work on the firm performance effects of employing undocumented workers. However, Champlin and Hake (2006) examine the increased need for short-term, low-skilled workers during the industrialization of the meatpacking industry from 1970-2002. They find that the presence of illegal immigrants within the factories reduced the bargaining power of shop workers and increased employer control.

The purpose of this paper is to determine whether there is any evidence of competitive advantage among firms that employ undocumented workers. If a competitive advantage is identified, this would be suggestive of monopsonistic discrimination; an absence of competitive advantage would suggest that the undocumented worker pay gap merely reflects productivity differences and costs of firms breaking the law. Results from the analysis in this paper will have implications for the impact of stricter immigration policies on product and labor markets, how effective those policies might be in modifying firm employment behavior, and from where opposition to or support for stricter policies might come.

\section{Theoretical Framework}

This section discusses how a wage gap could arise between documented and undocumented workers from a theoretical perspective. ${ }^{2}$ Depending on the source of the wage gap, firms employing undocumented workers may or may not receive a competitive advantage. The wage gap could simply reflect lower undocumented worker productivity. Undocumented workers may be systematically less well educated, have less work experience, and have poor

\footnotetext{
${ }^{2}$ We implicitly assume firms know whether a worker is documented or not, though in reality firms must conduct costly background checks to be sure. Among firms not wishing to employ undocumented workers, rather than go to the trouble of doing a background check, it is common practice to avoid workers with characteristics associated with undocumented status, such as English language ability and ethnicity. It may thus be more accurate to label the two groups "suspected documented workers" and "suspected undocumented workers".
} 
English language skills. ${ }^{3}$ Firms may also incur additional expenses from employing undocumented workers, such as fines, a loss of reputation, and costs of avoiding prosecution, so they may be willing to employ undocumented workers only if the wage is lower so as to compensate for such costs. Thus, a wage gap is not necessarily inconsistent with workers being paid their marginal products, and in such a scenario firms employing undocumented workers should receive no competitive advantage.

Discrimination against undocumented workers within firms that employ them could decrease productivity. If this isn't reflected in the wages paid to undocumented workers, firms employing them could have a competitive disadvantage. Perotin et al. (2003), for example, suggest that discriminated workers could be passed over for promotions and receive lower performance bonuses, not only reducing the workers' own productivity, but also generating negative spillovers for the firm as a whole (e.g., candidates for senior positions would be drawn from a smaller pool of workers). Undocumented workers may be expected to have lower future tenure in the firm either because they intend to return to their home country or because they may be deported. If expected tenure is low, the firm and the workers will have less of an incentive to invest in the match, also depressing productivity. Below we refer to the scenarios in this and the previous paragraph as productivity gap theories, as they assume that the wage gap can be explained by a productivity gap.

If, however, undocumented workers are just as productive as documented workers, and if firms are able to exercise monopsony power over undocumented workers as a result of low labor supply elasticities among these workers, then firms could pay these workers less than their marginal product and gain a competitive advantage. Undocumented workers need not even be as

\footnotetext{
${ }^{3}$ Borjas and Katz (2005) find that Mexican immigrants to the U.S. are much less educated than U.S. natives. Unfortunately, the Georgia administrative data do not contain proxies for worker productivity such as age, education, or work experience.
} 
productive as documented workers for firms to gain an advantage; they only need to be willing to accept a wage that is lower than their marginal revenue product. The model of monopsonistic discrimination was developed by Robinson (1933) to describe a labor market in which two groups of equally productive workers (men and women) are paid different wages because they differ in their elasticities of labor supply. Robinson theorized that women were paid less than men because they were limited in their alternative employment options as a result of their husbands' employment situations. ${ }^{4}$ The source of the firm's monopsonistic power in the labor market derives from the behavior of workers, not from the degree of competition in the firm's product market. In other words, the presence of a large number of competitive firms does not preclude monopsonistic discrimination. In fact, intense product market competition will put additional pressure on an employer to take advantage of differential labor supply elasticities across workers.

Using the same data employed in this study, Hotchkiss and Quispe-Agnoli (2008) present empirical evidence that the labor supply elasticity among undocumented workers is about half of that estimated for documented workers. Fear of deportation and limited employment opportunities could help account for the lower elasticity. In addition, Stark (2007) presents a compelling theoretical mechanism through which the work effort of undocumented workers is increased as their probability of deportation increases, which, in turn expands the wedge between undocumented worker productivity and their wage. Undocumented workers fearing deportation are unlikely to complain about low wages or poor employment environments. It is also not unreasonable to expect that the more employers to which undocumented workers expose themselves, the higher the risk of deportation. And it is likely that there are many firms that will

\footnotetext{
${ }^{4}$ Evidence of potential monopsonistic discrimination against women as a result of lower labor supply elasticities (relative to men) is provided by Hirsch et al. (2006) and Barth and Dale-Olsen (1999). Also see Bhaskar et al. (2002) for a review of evidence of monopsonistic competition more generally.
} 
simply refuse to hire undocumented workers and that undocumented workers are geographically constrained by the support (or lack) of social networks. All of these conditions reduce the employment opportunities of undocumented workers, ceteris paribus. ${ }^{5}$

In sum, the productivity gap theories do not predict any systematic patterns of undocumented worker employment across firms, and they imply that firms without undocumented workers will perform at least as well as those with them. The monopsonistic discrimination theory suggests that firms will enjoy a competitive advantage from employing undocumented workers at a below-marginal-product wage.

\section{Data}

The primary data used for the analyses in this paper are the Employer File and the Individual Wage File, compiled by the Georgia Department of Labor for the purposes of administering the state's Unemployment Insurance (UI) program. These data are highly confidential and strictly limited in their distribution. The data are available from the first quarter of 1990 through the fourth quarter of 2006. The Employer File provides an almost complete census of firms. In the U.S. as a whole, the Employer File covers approximately 99.7 percent of all wage and salary workers (Committee on Ways and Means 2004). ${ }^{6}$ The establishment-level information includes the number of employees, the total wage bill, and the NAICS classification of each establishment. The Individual Wage File is used to construct work force characteristics at the firm level. We take advantage of the longitudinal nature of the data to calculate the firm's age, employment variability, turnover rates, worker tenure, and most importantly, determination

\footnotetext{
${ }^{5}$ Semple (2008) offers anecdotal evidence that undocumented workers are at the mercy of their employers. An undocumented worker reported to Semple that an employer refused to pay him about $\$ 1,000$ he was owed for work performed, but that, "fear [of being deported] kept my mouth shut." In addition, Gibbons (2008) reports that a Pennsylvania firm assisted federal immigration agents in apprehending employees suspected of being undocumented.

${ }^{6}$ Certain jobs in agriculture, domestic services, and non-profit organizations are excluded from UI coverage; excluded workers are not represented in the data (Committee on Ways and Means 2004).
} 
of when the firm ceases operation. The data also contain a 6-digit NAICS industry code and the county of location, allowing us to construct or merge in various industry- and county-level indicators. Regrettably, the data set contains no information about workers' demographics or, more importantly, immigration status.

The specific variables used for the analyses will be described in the empirical specification section below.

\section{A. Identifying Invalid Social Security Numbers}

Every quarter employers must file a report with their state's Department of Labor detailing all wages paid to workers who are covered under the Social Security Act of $1935{ }^{7}$ Each worker on this report is identified by his/her social security number (SSN). There are a number of ways in which one can establish that a reported social security number is invalid. The Social Security Administration provides a service by which an employer can upload a file of SSNs for checking, but one must register as an employer to obtain this service. ${ }^{8}$ In addition, there are several known limitations on what can be considered a valid social security number, so a simple algorithm is used to check whether each number conforms to the valid parameters.

There are three pieces to a SSN. ${ }^{9}$ The first three numbers are referred to as the Area Number. This number is assigned based on the state in which the application for a SSN was made; it does not necessarily reflect the state of residence. The lowest Area Number possible is 001 and the highest Area Number ever issued, as of December 2006, is 772. Using information provided by the SSA, the dates at which area numbers between 691 and 772 are first assigned can be determined. Any SSN with an Area Number equal to 000, greater than 772, or which

\footnotetext{
${ }^{7}$ For information about which workers are covered, see U.S. Department of Labor (2008).

${ }^{8}$ See Social Security Number Verification Service <http://www.ssa.gov/employer/ssnv.htm>.

${ }^{9}$ Historical information and information about valid SSNs can be found at the Social Security Administration's web sites: <http://www.ssa.gov/history/ssn/geocard.html> <http://www.socialsecurity.gov/employer/stateweb.htm>.
} 
shows up before the officially assigned date, will be considered invalid. ${ }^{10}$

The second piece of a SSN consists of the two-digit Group Number. The lowest group number is 01 , and they are assigned in non-consecutive order. Any SSN with a Group Number equal to 00 or with a Group Number that appears in the data out of sequence with the Area Number will be considered invalid.

The last four digits of a SSN are referred to as the Serial Number. These are assigned consecutively from 0001 to 9999. Any SSN with a Serial Number equal to 0000 will be considered invalid.

In 1996 the Internal Revenue Service (IRS) introduced the Individual Tax Identification Number (ITIN) to allow individuals who had income from the U.S. to file a tax return. It is simply a "tax processing number," and does not authorize an individual to work in the U.S. Employers are instructed by the IRS to "not accept an ITIN in place of a SSN for employee identification for work. An ITIN is only available to resident and nonresident aliens who are not eligible for U.S. employment and need identification for other tax purposes." ${ }^{11}$ ITIN numbers have a "9" in the first digit of the Area Number and a "7" or "8" in the first digit of the Group Number. Anyone with this numbering scheme will be identified as having an invalid Area Number, as they are not authorized to work. The percent of SSN with high area numbers that also match the ITIN numbering scheme has risen from about one percent in 1997 to over 60 percent by the end of 2006.

A series of SSNs were de-commissioned by the Social Security Administration because they had been put on fake Social Security Cards used as props to sell wallets. Apparently, some

\footnotetext{
10 See <http://www.ssa.gov/employer/ssnvhighgroup.htm>.

11 "Hiring Employees," < http://www.irs.gov/businesses/small/article/0,,id=98164,00.html>. Also see, "Individual Taxpayer Identification Number (ITIN)," <http://www.irs.gov/individuals/article/0,,id=96287,00.html>. ITIN numbers were first issued in 1997.
} 
people who purchased the wallets thought the fake Social Security Cards were real and started using them as their own (See U.S. Department of Housing and Urban Development 1990). If any of these 21 "pocketbook" SSNs appear in the data, they are considered invalid, although their frequency is so low as to be inconsequential. In addition, a number of SSNs are exactly equal to the employer identification number. These are considered invalid. In any instance where a SSN is used for more than one person on a firm's UI wage report or does not have the required number of digits (including zeros), the SSN will also be considered invalid.

The possibility that someone fraudulently uses a valid SSN assigned to someone else poses a special problem. First of all, the SSN will show up multiple times across firms in one quarter for workers with different surnames (the wage report includes the first three letters of the workers' surnames). With this information alone, it is not possible to know which worker is using the SSN fraudulently and which is the valid owner of the number. If one of the SSN/surname pairs shows up in the data initially in a quarter by itself, this is the pair that is considered valid and all other duplicates (with different surnames) are considered invalid.

\section{B. Does "Invalid" mean "Undocumented?"}

Examining the patterns of incidence of different types of invalid SSNs suggests that some types are firm generated rather than worker generated. Figure 1 illustrates the incidence patterns across types of invalid SSNs in the construction sector. This pattern is consistently found in the other sectors as well. The percent of workers with SSNs having a high area number or out-ofsequence group number displays the expected growth in undocumented workers (see Hoefer et al. 2007), whereas the incidence of SSNs for other reasons exhibits a flat to declining, highly seasonal pattern. The strong seasonal nature of the other invalid reasons suggests that firms are temporarily assigning invalid SSN numbers to workers before having time to gather the 
information for the purpose of record keeping/reporting. ${ }^{12}$ Or, firms may decide to not bother obtaining SSNs for workers who will only be employed a very short time. The high degree of churning observed among invalid SSNs for these other reasons is consistent with either of these practices. $^{13}$

[Figure 1 here]

Since there is no way to know whether a temporary assignment by the firm of an invalid SSN is to merely cover for temporary employment of an undocumented worker or to allow the firm to file its wage report before having had a chance to record the worker's valid SSN, the analysis below takes the conservative tack by considering as undocumented only those workers whose SSNs are classified as invalid because the area number is too high or the group number is assigned out of sequence. This will clearly undercount the actual number of undocumented workers, so that any effect identified in the analysis will also likely under-estimate the true effect of the presence of undocumented workers on firm exit. ${ }^{14}$ We take pains, however, to not include workers with invalid SSNs for these other reasons in the construction of a firm's worker characteristics (such as average worker tenure). However, they are included in counts of aggregate firm employment.

Figure 2 plots the prevalence of undocumented workers in the six broadly defined sectors with the highest incidences (excluding agriculture, which is presented in Figure 4). The concentration of workers in these sectors was also identified nationally by Fortuny et al.

\footnotetext{
${ }^{12}$ If a SSN has a high area number or out-of-sequence group number as well as being invalid for other reasons, the SSN is included in the invalid for other reasons group. Here we report all other reasons together due to space constraints. We have examined each of them separately, and they display similar patterns.

${ }^{13}$ The average quarterly churning rates (accessions plus separations minus the net employment change, all divided by average employment in the quarter) for SSNs with invalid area numbers, invalid group numbers, duplicate SSNs with different surnames, and invalid for other reasons are $26.9 \%, 55.7 \%, 188.3 \%$, and $215.6 \%$, respectively. In addition, a worker has 90 days to resolve a discrepancy that results in the receipt of a "no-match" letter from the Social Security Administration. The employee may be long gone before such a letter is even received.

${ }^{14}$ All analyses were repeated for workers with invalid SSNs for other reasons, yielding similar results; these will be discussed further below.
} 
(2007) ${ }^{15}$ The pattern of growth, with recent exponential increases, is also consistent with Fortuny et al. who estimate that 72 percent of unauthorized immigrants in Georgia arrived in the last 10 years. Figure 3, showing the share of firms employing undocumented workers, reflects the same pattern of growth.

[Figures 2 and 3 here]

The percent of workers that is undocumented and the share of firms employing undocumented workers in agriculture are shown together in Figure 4. By 2006, the share of firms employing undocumented workers reached about 20 percent--less than the share in leisure and hospitality, but more than in the rest of the sectors. The share of workers in the agricultural sector that is undocumented is at least twice as large as the share of workers in any of the other sectors, and the seasonal pattern of employment is much more dramatic.

[Figure 4 here]

Fortuny et al. (2007) estimate that 4.5 percent of the workforce in Georgia was undocumented in 2004. In our sample 1.2 percent of workers are classified as undocumented in 2004. The implication is that the sample used for the analysis in this paper is capturing about 26 percent of all undocumented workers in the state of Georgia. This is a respectable representation, given that to be included in the sample an undocumented worker must be reported by the employer to the Department of Labor in the first place, and that we are being very conservative in the identification of workers as undocumented. Since we capture a limited percentage of the actual number of undocumented workers, we expect the results to reflect a lower-bound on the estimated influence of undocumented workers on firm survival.

\footnotetext{
${ }^{15}$ Fortuny et al. (2007) estimate that nationally in 2004 the percent of workers in leisure and hospitality and construction that was undocumented was 10 percent each, nine percent of workers in agriculture, and six percent each in manufacturing, professional and business services, and other services.
} 


\section{Are Undocumented Workers Correctly Identified?}

It is crucial to establish confidence in the mechanism employed to identify undocumented workers. The best information at hand for doing this is to compare the geographic distribution or concentration of undocumented workers (and firms that employ them) with some external source of information about the distribution or concentration of unauthorized immigrants. The Department of Homeland Security estimates for January 2006 that 57 percent of unauthorized immigrants come from Mexico (Hoefer et al. 2007). Clearly not all Hispanic individuals are unauthorized immigrants, but a first test of the accuracy of identifying undocumented workers might be to compare the geographic distribution of those identified as undocumented for the purposes of analysis in this paper and the geographic distribution of various ethnic and racial groups across counties in the state. Table 1 presents these correlation coefficients for 2005.

[Table 1 here]

The correlation between the percent of the county population that is Hispanic and the percent of workers in the county identified as undocumented is 0.18 (of course, some individuals may live and work in different counties). The correlations with the percent that is Asian and the percent that is African American in the counties are both negative. The correlation of the percent of firms in the county employing undocumented workers with ethnicity is also positive and highest as it relates the percent of the county population that is Hispanic (0.38). The correlation of the presence of these firms with percent of the county population that is Asian is also positive, but smaller at 0.27; the correlation with the percent of the population that is African American is again negative.

Additionally, the rate of growth seen in both the number and percent of undocumented workers identified in Georgia matches closely the rate of growth in the Social Security 
Administration's (SSA) earnings suspense file (ESF). The ESF is a repository of social security taxes paid by employers that cannot be matched to a valid name or SSN. Figure 5 plots the number of workers identified (panel a) and the percent of workers identified (panel b) as undocumented along with the size of the ESF. This figure shows a remarkable consistency between the growth seen in workers identified as undocumented and the ESF. Payments on wages in the ESF reflect only about four percent of all initial non-matching earnings reports (the others were resolved through an error identification process). In addition, about 43 percent of employers associated with wage payments that end up in the ESF come from only five of 83 broad industry classifications, with eating and drinking establishments (leisure and hospitality, 17 percent) and construction (10 percent) being the largest contributors (Bovbjerg 2006).

[Figure 5 here]

The positive correlation between the Hispanic population across counties in Georgia and the percent of workers identified as undocumented for this analysis, as well as closely matching growth in undocumented workers identified in Georgia and growth in the SSA ESF independently suggest that the mechanism employed in this paper to identify undocumented workers is accurate.

\section{Sample Means}

Table 2 presents some sample means for all firms, firms that do not employ any undocumented workers, and firms that employ at least one undocumented worker. Means from 1995 and 2005 are presented separately; they correspond to the actual estimating sample (the reason for limiting the estimation to the years 1995-2005 is explained below).

[Table 2 here]

The employment of undocumented workers has increased over time. The share of firms 
in Georgia employing undocumented workers doubled from four percent in 1995 to over eight percent in 2005. Among firms employing at least one undocumented worker, these workers made up about seven percent of a firm's work force, on average, in 1995, but over 11 percent in 2005. Larger, multi-establishment, and slightly older firms are more likely to employ undocumented workers. The average firm size among firms employing undocumented workers has come down significantly over time, indicating that more small (and more singleestablishment) firms employ them in 2005 than in 1995. In addition, average worker tenure is lower among firms employing undocumented workers. These characteristics of firms employing undocumented workers are consistent with those identified by Morales (1983-1984).

\section{Empirical Specifications}

The goal of the empirical analysis is to determine whether the practice of employing undocumented workers gives firms a competitive advantage. As the data allow us to identify when a firm ceases to operate, but they do not contain profit, value added, or sales, we have chosen to use survivability as our proxy for competitive advantage. A firm is considered to have exited when a quarter of positive employment is followed by four quarters of zero employment. The basic exit equation is specified as follows:

$$
\mathrm{P}\left[\mathrm{Exit}_{\mathrm{jisct}}\right]=\beta_{0}+\beta_{1}^{\prime} \mathrm{X}_{\mathrm{jt}}+\beta_{2}^{\prime} \mathrm{Y}_{\mathrm{it}}+\beta_{3}^{\prime} \mathrm{W}_{\mathrm{st}}+\beta_{4}^{\prime} \mathrm{G}_{\mathrm{ct}}+\delta * \mathrm{UNDOC}_{\mathrm{jt}}+\varepsilon_{\text {jisct }}
$$

where firm $j$ 's probability of exit in time $t$ is determined by firm-specific characteristics in $t, \mathrm{X}_{\mathrm{jt}}$; the firm's industry-specific characteristics at time $t, \mathrm{Y}_{\mathrm{it}}$; the firm's sector-specific characteristics at time $t, \mathrm{~W}_{\mathrm{st}}$; the firm's geographic county-specific characteristics, $\mathrm{G}_{\mathrm{ct}}$; and whether or not the firm employs undocumented workers in time $t, \mathrm{UNDOC}_{\mathrm{jt}}=0,1 .{ }^{16}$ The firm's industry reflects

\footnotetext{
${ }^{16}$ We measure undocumented employment as a $(0,1)$ dummy variable rather than as the number or share of undocumented workers employed by the firm, because the data appear to do a much better job of identifying the
} 
the 2002 6-digit NAICS classification. The firm's sector is an aggregated grouping based on the NAICS. Appendix A contains a table of sector definitions. In addition to the regressors of interest, year-quarter fixed effects and 3-digit industry fixed effects are included in all estimations to control for quarterly aggregate variation in exit rates and for time-invariant industry-specific influences on firm performance, such as technologically-intensive or laborintensive production processes (see Cortes 2008). ${ }^{17}$ Standard errors are adjusted for clustering at the firm level. Parameter estimates are obtained through maximum likelihood probit estimation.

\section{A. Firm-Specific Characteristics}

Characteristics of the firm include age (and its square); employment size dummies; average quarterly wage (and its square) among documented workers; the share of documented workers that is "part-time employed" (workers earning less than \$3,000 in a given quarter, which is approximately the full-time minimum wage); a dummy equal to one if the establishment is part of a multi-establishment firm; the firm's rate of worker churning among its documented work force; average tenure among documented workers; and average cumulative employment variability, which is calculated as the variance in total employment levels from the first quarter in the data set to the current time period.

Older firms should be less likely to exit, as they tend to have high productivity--otherwise they would have already exited. In addition, large firms tend to be more productive, so they should also have a lower exit propensity. ${ }^{18}$ Efficiency wage theory suggests that higher paying firms will also be more productive, thus less likely to exit (Akerlof and Yellen 1990), and a

firms that employ undocumented workers than the numbers of undocumented workers they employ. To give just one example, Table 1 shows a significantly higher correlation between a county's Hispanic population share and the percent of firms employing undocumented workers (38\%) than with percent of workers (18\%). This will be discussed further below.

${ }^{17}$ The transport and utility sector regressions include fixed effects at a more aggregated 2-digit level, because insignificant 3-digit industry dummies prevented the regressions from achieving convergence.

${ }^{18}$ These relationships between firm age, size, and exit are predicted by the Jovanovic (1982) and Ericson and Pakes (1995) models of firm selection. 
greater share of part-time workers might be detrimental to performance because of greater wage dispersion within the firm (Winter-Ebmer and Zweimüller 1999).

A multi-establishment firm may be less likely to shut down since it can close individual establishments if necessary without shutting down completely. High worker churning is likely to add to the firm's labor costs, thus positively affecting EXIT. ${ }^{19}$ Having a work force with higher human capital would also make a firm more productive, thus reduce exit propensity. Higher average worker tenure reflects a higher level of firm-specific human capital. High employment variability may reflect a degree of instability, thus a higher propensity to exit, or a firm that is nimble in adjusting to product demand, thus reducing the propensity to exit.

\section{B. Industry-, Sector-, and County-Specific Characteristics}

Growth of the firm's industry over the previous year and growth of the firm's sector in the firm's county, as measured by employment growth (calculated using the Davis and Haltiwanger 1992 method), are included as measures of the strength in the firm's industry overall and in the firm's broader sector more geographically specific to the firm's location. Expansion in the sector and locality should support a larger number of firms and hence less exit. Additional regressors are added to account for overall economic demand and consumption that the firm might face in its locality: county population growth; log county per-capita income (measured in $\$ 1,000$ s); and the proportion of total public school enrollment in the county that is eligible for free and reduced price school lunch, a poverty-level proxy. The free and reduced lunch variable is measured only in October in each year and is assigned to all quarters in the following calendar year. This regressor is available only starting in 1995 and thus limits the final analyses to the years 1995 through 2005.

\footnotetext{
${ }^{19}$ Including this variable at least partially controls for the possibility that not all firms report their undocumented workers to the Department of Labor. As mentioned above, firms may be less likely to include undocumented workers on their UI wage report if the firm's separation experience has resulted in a higher UI tax rate.
} 
All analyses will be estimated separately by sector, allowing the impact of employing undocumented workers (and the other regressors) on exit probability to fully vary by sector. Figure 3 shows that the incidence of undocumented employment is quite uneven across sectors (and there are five other sectors not shown in the figure with even lower incidences of undocumented employment). Among other things, the estimation of separate sector-level results will allow us to explore whether the competitive advantage from employing undocumented workers is associated with the prevalence of the practice.

One industry-specific measure deserves special consideration. Just as a firm's own employment of undocumented workers could give it a comparative advantage, undocumented employment by competitors could place the firm at a disadvantage. To test this, we include a variable measuring the proportion of other firms in the firm's 6-digit NAICS industry that employ undocumented workers: IndUNDOC.

The influence of competitors' undocumented employment behavior may vary with the geographic size of the product market. In markets where firms supply a geographically broad product market, they may shift labor-intensive parts of their business to developing countries, where low-cost labor is both legal and plentiful (for example see Preston 2007). In such cases, local competitors' undocumented employment behavior is unlikely to affect the firm. But in geographically segmented markets, where each firm supplies their product to a smaller geographic area, firms do not have the option to conduct low-skilled labor production offshore, making the use of undocumented employment in the local market a more important tool for gaining a competitive advantage. To measure geographic market size, we calculate BroadMarket, which is a modified Duncan index of dissimilarity (Duncan and Duncan 1955):

$$
\mathrm{D}_{\mathrm{i}}=\frac{1}{2} \sum_{\mathrm{c}=1}^{\mathrm{N}_{\mathrm{c}}}\left|\frac{\mathrm{e}_{\mathrm{ic}}}{\mathrm{E}_{\mathrm{i}}}-\frac{1}{\mathrm{~N}_{\mathrm{c}}}\right|
$$


where $\mathrm{N}_{\mathrm{c}}$ is the number of counties (159), $\mathrm{e}_{\mathrm{ic}}$ is the number of workers in industry $i$ that are in county $c, \mathrm{E}_{\mathrm{i}}$ is the total employment in industry $i, 1 / \mathrm{N}_{\mathrm{c}}$ is the share of workers that would need to be employed in each county for there to be an equal distribution of workers in the industry across counties. The closer $\mathrm{D}_{\mathrm{i}}$ gets to 0 (more equally distributed workers), the more diversified the industry and the more local the market. The closer D gets to 1 , the more concentrated is employment in that industry and thus serving a broader market. "Broad," in this case, of course, means extending outside of Georgia. BroadMarket is interacted with IndUNDOC to test the hypothesis that other firms' undocumented employment behavior matters more in geographically segmented markets.

\section{Issues of Endogeneity}

It is likely that several of the regressors in equation (1) are endogenous to the determination of a firm's exit outcome. More specifically, some regressors may be correlated with the error term, or their observed values in time $t$ may be affected by the firm's process of exiting. For example, if a firm is not doing well and showing signs of distress (likely to exit), the workers might become anxious or dissatisfied, resulting in a high turnover rate, measured by the degree of worker churning. In addition, a firm anticipating shutting down may adjust its employment level or employment mix (documented vs. undocumented) a couple of quarters prior to shutting down. Given the limited nature of the data, and since there is no hope of instrumenting all these regressors, we take a mixed approach.

For most of the regressors, lagged values are used to move them further from the time of exit itself. IndUNDOC, the employment dummies, average wage, part-time workers, employee churning, log tenure, and log employment variability are all lagged one year (four quarters); industry growth and county sector growth correspond to the growth experienced in the previous 
year (lagged one quarter, i.e., between five quarters and one quarter before exit). We account for the potential endogeneity of $U N D O C$, a regressor of particular interest, in an alternative way. The measured impact of employing undocumented workers on performance is likely intimately related to the firm's decision to employ undocumented workers in the first place. Accounting for unobserved factors that simultaneously influence the employment and reporting decision as well as the exit outcome is best handled through estimation of a recursive bivariate probit model (Greene 1996, 1998; Baslevent et al. 2007).

The probability that a firm employs undocumented workers is specified as follows:

$$
\begin{aligned}
\left.\mathrm{P}_{\left[\mathrm{UNDOC}_{\mathrm{jist}}\right.}\right] & =\alpha_{0}+\alpha_{1}^{\prime} \mathrm{X}_{\mathrm{jt}}+\alpha_{2}^{\prime} \mathrm{Y}_{\mathrm{it}}+\alpha_{3}^{\prime} \mathrm{W}_{\mathrm{st}}+\alpha_{4}^{\prime} \mathrm{G}_{\mathrm{ct}} \\
& +\alpha_{4} \mathrm{POPDEN}_{\mathrm{ct}}+\alpha_{5} \mathrm{HISPENROL}_{\mathrm{ct}}+\alpha_{6} \mathrm{CS}_{-} \mathrm{UNDOC}_{\mathrm{ct}-4}+v_{\mathrm{jist}}
\end{aligned}
$$

where $\mathrm{X}_{\mathrm{jt}}, \mathrm{Y}_{\mathrm{it}}, \mathrm{W}_{\mathrm{st}}$, and $\mathrm{G}_{\mathrm{ct}}$ are all as described above. POPDEN $\mathrm{ct}_{\mathrm{ct}}$ is the log of population density (measured in 1,000s of persons per square mile) in the firm's county at time $t$; HISPENROL $_{\mathrm{ct}}$ is the proportion of public school enrollment in the firm's county at time $t$ that is Hispanic; ${ }^{20}$ and $\mathrm{CS}_{-} \mathrm{UNDOC}_{\mathrm{ct}-4}$ is the proportion of the firm's sector, in the firm's county, that employed undocumented workers four quarters previously. These last three regressors are included to improve model identification, and they all (or a subset of them, depending on the sector) contribute significant explanatory power to the firm's employment decision. ${ }^{21}$

Technically, what equation (3) is describing is the probability of the joint decision by the firm to employ and report the employment of undocumented workers. It is likely that some firms employ undocumented workers, but do not report them on formal wage reports to the

\footnotetext{
${ }^{20}$ We use Hispanic public school enrollment because Hispanic population is only available on an annual basis since 2000. Hispanic public school enrollment is only available starting in 1995, which is an additional reason why our regression analysis starts in that year.

${ }^{21}$ Wilde (2000) shows that exclusion restrictions are not necessary for identification with a bivariate probit model, but Monfardini and Radice (2008) provide evidence suggesting that exclusion restrictions improve the reliability of exogeneity tests.
} 
Department of Labor. There is no way to distinguish these firms from those not employing undocumented workers. Informal conversations with employers and immigration lawyers have led us to believe that a firm is more concerned with penalties associated with not paying employment taxes (e.g., unemployment insurance, workman's compensation, Medicaid) than they are about immigration enforcement. ${ }^{22}$ In other words, we expect that if a firm employs undocumented workers, it is likely to report those workers, or at least some of them, on the UI wage report.

An additional identification problem arises in the specification and estimation of equation (3), namely, the "reflection problem" identified by Manski (1993). The problem arises because the dependent variable (Prob[UNDOC]=1) is a function of the outcomes observed for other members of the firm's "group," which in this case is firms in the same industry (IndUNDOC) and the same county-sector (CS_UNDOC). The IndUNDOC and CS_UNDOC effects could be positive not because a firm's behavior varies with the behavior of its group (endogenous effects), but instead because of contextual or correlated effects. Some uncontrolled factor in common to each of the firms in the group could affect the undocumented employment decision.

Unfortunately, data limitations preclude us from instrumenting the social effect of interest (IndUNDOC). However, Manski points out that in the case of dynamic models like equation (3), the social effect is identified if the dynamic structure imposed is correct. We are assuming that a firm's decision to employ undocumented workers at time $t$ is related to other firms' decisions made in time $t-4$ (one year ago). This assumption is not entirely unreasonable, as the groups are

\footnotetext{
${ }^{22}$ U.S. Immigration and Customs Enforcement (ICE) describe their priorities in undertaking raids on firms suspected of employing undocumented workers (http://www.ice.gov/pi/worksite/index.htm). The first priority includes work sites critical to infrastructure and national security. Secondarily, "Worksite Enforcement investigations focus on egregious employers involved in criminal activity or worker exploitation." Employers who continually report a large number of workers whose names and SSNs do not match (as determined by the SSA) are the most likely targets. This is an additional reason why we have more confidence in our identification of firms employing and reporting behavior than in the actual number of undocumented workers employed.
} 
based on loose connections (industry and county location) rather than on daily contact (as might be the case when defining a group for members of the same family, for example).

\section{Results}

Table 3 contains parameter estimates and marginal effects from estimation of equations (1) and (3) via maximum likelihood bivariate probit. ${ }^{23}$ As suggested by Greene (1998), results corresponding to fixing the correlation coefficient to zero are reported for sectors where the likelihood ratio test of $\rho=0$ is insignificant at the 90 percent confidence level. ${ }^{24}$

[Table 3 here]

\section{A. The Firm's Undocumented Employment Decision}

Older and larger firms are more likely to employ undocumented workers. This is consistent with older firms having better developed access to undocumented worker supplies and larger firms having more sophisticated record keeping that increases the likelihood that any undocumented worker that is employed is also reported. With the exception of agriculture, construction, financial services, and other services, multi-establishment firms are more likely to employ undocumented workers. Firms in all sectors, except transportation and utilities, are more likely to employ undocumented workers if they experience greater workforce churning, and in all cases employment variability is positively associated with the propensity to employ undocumented workers. These results are consistent with Morales (1983-1984), who concludes from her case study of automobile manufacturers in Los Angeles that subsidiaries (part of a multi-establishment firm) and firms with high turnover and employment variability are more likely to employ undocumented workers. She argues that subsidiaries might have extra pressure from a parent company to show a profit and are thus more motivated to cut costs by employing

\footnotetext{
${ }^{23}$ The marginal effects are evaluated at each observation, then averaged over the sample (see Greene 1996). The standard errors are bootstrapped using 500 repetitions.

${ }^{24}$ Monfardini and Radice (2008) show that the likelihood ratio test is the preferred test in this case.
} 
undocumented workers. In addition, firms with high employment variability (and churning) are likely to need a very flexible work force, and it is thought that undocumented workers are easy to hire and fire as demand conditions dictate.

The three regressors unique to the employment equation are POPDEN, HISPENROL, and CS_UNDOC. All these regressors are important in explaining a firm's probability of employing undocumented workers, but they do not help explain firm exit propensity. ${ }^{25}$ The coefficient estimates indicate that a firm located in a more densely populated county (most sectors) and in a county with a greater share of public school enrollment that is Hispanic is more likely to employ undocumented workers. These regressors appear to do a good job as proxies for the supply of undocumented worker labor available to the firm.

The industry, county-sector, and county population growth coefficients are positive in most cases. This is consistent with firms using undocumented labor during times of peak demand (when the documented worker labor market is tight) rather than as a desperation measure when distressed. The estimated positive and significant coefficient on CS_UNDOC is consistent with a herding mentality found by others at the firm level regarding illegal behavior (see Earle and Peter, forthcoming); a culture of acceptable behavior develops as more employers hire undocumented workers. It could also be the case that observed success in getting away with the behavior encourages more risk averse firms to jump on the bandwagon. This regressor's coefficient is negative only in the information sector. The positive and significant coefficient on IndUNDOC provides additional support for herding behavior.

Firms in broad product markets are found to be significantly less likely to employ undocumented workers, as expected given that only such firms have the opportunity to conduct

\footnotetext{
${ }^{25}$ POPDEN is excluded from the retail trade and financial services sector estimations; that regressor shows some explanatory power in determining exits in those sectors. HISPENROL is excluded from the estimations for the transportation \& utilities and education \& health sectors for the same reason.
} 
labor-intensive parts of their business abroad. A negative and (mostly) significant coefficient on the interaction of IndUNDOC with BroadMarket suggests that herding behavior is also less strong in such sectors.

\section{B. Firm Survival}

The parameter estimates in the exit equation conform to well-established relationships between firm characteristics and firm survival (for example, see Disney et al. 2003 and Dunne et al. 1989). Young firms, small firms, those with a high degree of employment variability, and ones with low worker tenure are more likely to exit. For the most part multi-establishment firms and firms in an industry experiencing faster employment growth have a reduced probability of exiting. Firms with greater churning experience a lower probability of exit; churning may reflect a degree of nimbleness important for survival. The county-level regressors perform at different significance levels and in different directions across sectors; these are likely correlated with other regressors in different ways across sectors.

The coefficients on the UNDOC regressor are significantly negative for all sectors. The marginal effects indicate that employing undocumented workers reduces the probability of a firm exiting between 0.2 of a percentage point (in education and health) to 1.3 percentage points (in other services). Employing undocumented workers reduces a firm's probability of exiting by 0.8 of a percentage point in construction and professional and business services, by about 0.7 of a percentage point in agriculture, and by 0.5 of a percentage point in both manufacturing and leisure and hospitality. Given that the predicted probability of a firm exiting in any sector is roughly two percent, employing undocumented workers could halve a firm's probability of exiting.

In addition, a firm's exit probability is almost uniformly increased across sectors when 
other firms in the industry employ undocumented workers. This makes sense if doing so also gives other firms a competitive advantage, and it is consistent with anecdotal evidence obtained from interviews with firms and from Congressional testimony, in which employers report that they feel a need to hire undocumented workers to stay competitive, because competitors employing undocumented workers are able to undercut their prices. ${ }^{26}$ The fact that the IndUNDOC marginal effect is significantly larger than that of $U N D O C$ in most sectors implies that firms would be better off if they could all commit to not employing undocumented workers. It also implies that profit margins are pushed lower as more firms employ undocumented workers, suggesting that consumer prices are lower in these sectors as well. This is consistent with the work by Cortes (2008) that finds that the price of immigrant-intensive services are pushed lower in areas experiencing increases in the share of low-skilled immigrants.

The negative (when significantly different from zero) coefficient on the interaction of IndUNDOC with BroadMarket indicates that undocumented employment is less of a competitive factor when firms have the option to move labor-intensive parts of their business out of state (or offshore). Notably, this coefficient is significant in sectors where some industries are global (e.g., in manufacturing, financial services, and professional and business services).

\section{Results for Workers with Invalid SSNs for Any Reason}

The results reported in this paper correspond to the impact of employing workers for whom we are most confident of the "undocumented" designation. As mentioned earlier, it is not at all clear whether workers with invalid reasons other than having a high area number or out-of-sequence group number are documented or not. Some of the other reasons appear to be record-keeping short-cuts allowing firms to complete their paperwork for workers who may only

\footnotetext{
${ }^{26}$ For example, see the testimony of Charles Shafer, carpenter from Lawrenceville, GA (Subcommittee on Workforce Protections of the Committee on Education and the Workforce, 2006, pp. 25-6).
} 
be employed one quarter, or for whom the employer has yet to obtain valid SSNs. In these cases, the employer may just record zeros, their own employer ID, or repeat the same number for multiple workers. In the case of the same valid SSN appearing for workers with different surname initials at different employers, it is not known to which worker the valid SSN truly belongs. Informal conversations with immigration lawyers and members of the undocumented community confirm that selling valid SSNs is a common practice.

In cases where employers assign an invalid SSN to workers employed on a very shortterm basis, or where there are repeated valid SSNs across workers with different surnames, it is likely that a significant number of these workers are actually undocumented. As a limited test of this assertion, the full analysis has been repeated to determine whether employing workers with invalid SSNs for reasons other than a high area number or out-of-sequence group number have a similar impact on firm performance as employing workers that are more confidently in the "undocumented" category.

The directional impact and significance levels of the regressors from the bivariate probit estimation when an indicator for workers with invalid SSNs for reasons other than high area number or out-of-sequence group number replaces $U N D O C$ generally match those presented in Table 3. However, the impact on a firm's exit probability of employing workers with these other invalid SSNs, or being in an industry that employs more of these workers, is weaker than when considering those we classify as undocumented. This is to be expected if some workers have invalid SSNs merely as a short-term convenience for the firm, but are indeed documented workers. ${ }^{27}$

\footnotetext{
${ }^{27}$ The full set of estimation results is available on request.
} 


\section{Conclusion}

The results of the analysis in this paper indicate that firms employing undocumented workers enjoy a competitive advantage over firms that do not employ undocumented workers. Others have identified a sizeable wage gap between documented and undocumented workers, with undocumented workers being paid about 30 percent less than documented workers (Hotchkiss and Quispe-Agnoli 2008). Whether this wage gap results in cost savings for employers, thus improving their competitiveness, depends on its source. If the wage gap compensates for lower productivity among, or higher risk from employing undocumented workers, then firms employing undocumented workers should experience no competitive advantage. If, on the other hand, firms are able to distinguish between groups of workers and one group has a lower labor supply elasticity, the firm can gain a competitive advantage by paying those workers a wage below their marginal revenue product. This wage-setting practice is referred to as monopsonistic discrimination. The analysis in this paper provides evidence consistent with employers' ability to sustain monopsony power over undocumented workers.

There are both economic and political implications from finding that firms experience a competitive advantage from employing undocumented workers. From an economic perspective, any reduction in the supply of undocumented workers (e.g., through tougher border and worksite enforcement) will raise firms' production costs and, likely, prices paid by consumers in those sectors employing larger shares of undocumented workers.

From a political perspective, the results of this paper provide strong predictions about the sources of lobbying about and potential effectiveness of immigration policies designed to reduce the supply of undocumented workers. Resistance to tougher enforcement is likely to come from employers in industries where undocumented employment is pervasive, such as agriculture, 
construction, leisure and hospitality, and industries in other sectors where markets are geographically segmented. Groups representing documented workers in those same sectors are likely to call for tougher enforcement due to their depressed wages resulting from undocumented employment. In sectors where undocumented employment is uncommon, but the competitive effects are strong (e.g., in transport and utilities and wholesale trade) individual firms employing undocumented workers may wish to quietly lobby against tougher enforcement, but industrywide employer resistance and documented employee calls for enforcement are unlikely. ${ }^{28}$

In addition, local initiatives to enforce immigration law are likely to be more effective at curbing employment of undocumented workers within geographically segmented industries, as firms in these industries don't have an option to move production elsewhere while continuing to serve the local market. In contrast, firms facing product markets that extend beyond the county or state borders can respond to stricter immigration enforcement by shifting production to counties or states with more lax immigration enforcement. If immigration is enforced more strictly nationally, companies may shift production abroad.

The identification of a competitive advantage accruing to firms that employ undocumented workers suggests that they are exercising some monopsony power in the labor market for these workers. Consequently, if immigration policies predicated on workers' rights and moral obligation (see Gibbons 2008 and Greenhouse 1999) are successful in forcing firms to treat undocumented workers in the same way as documented workers, their competitive advantage may disappear, lowering demand for undocumented workers.

\footnotetext{
${ }^{28}$ Immigration lawyers have informed us that firms lobbying for softer immigration enforcement keep a low profile in order not to draw attention to their violation of the law.
} 
Figure 1.

Percent of workers with invalid SSN, by reason, construction, 1990:1 - 2006:4

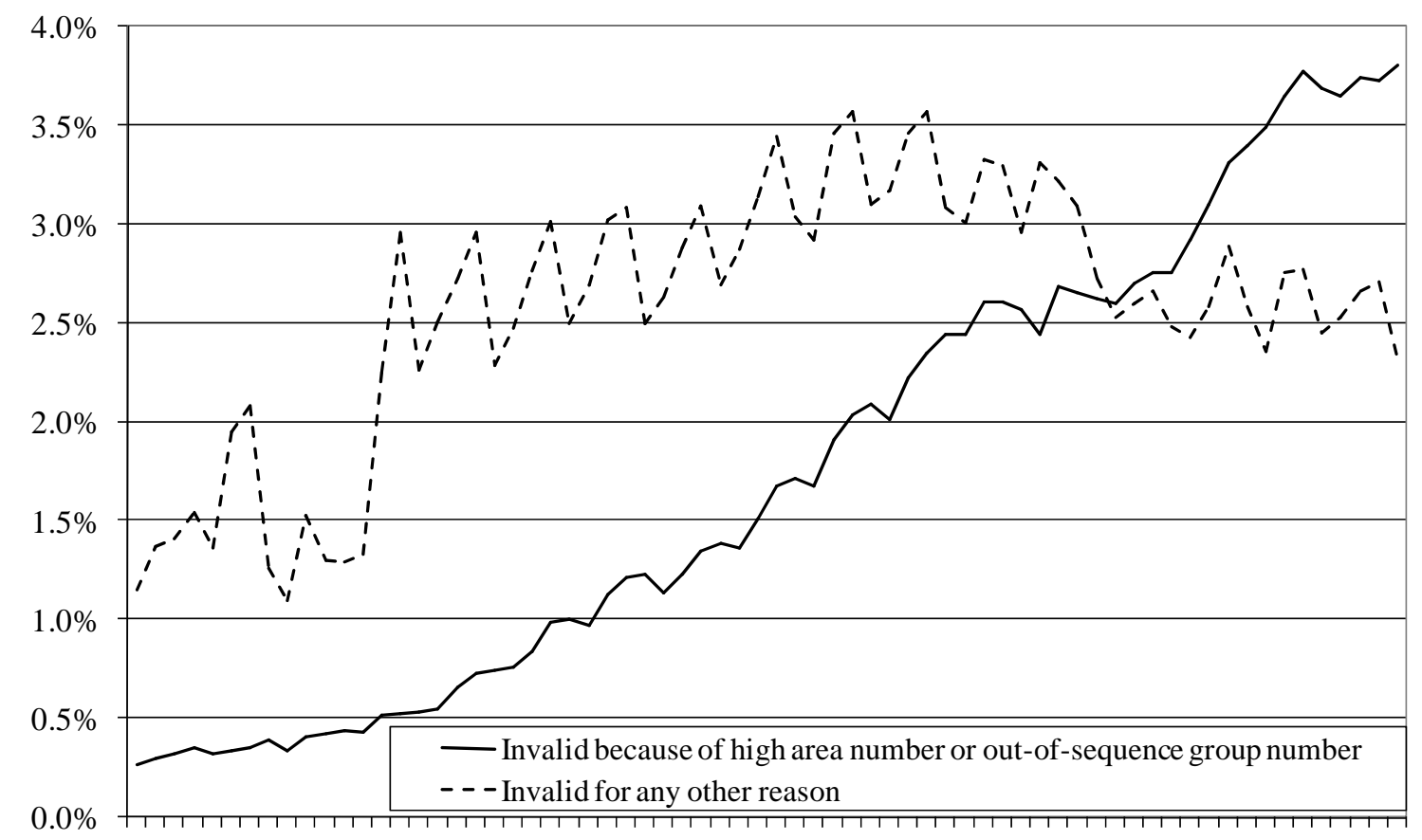

19901991199219931994199519961997199819992000200120022003200420052006

Figure 2.

Percent of workers that is undocumented by broad industry, 1990:1 - 2006:4

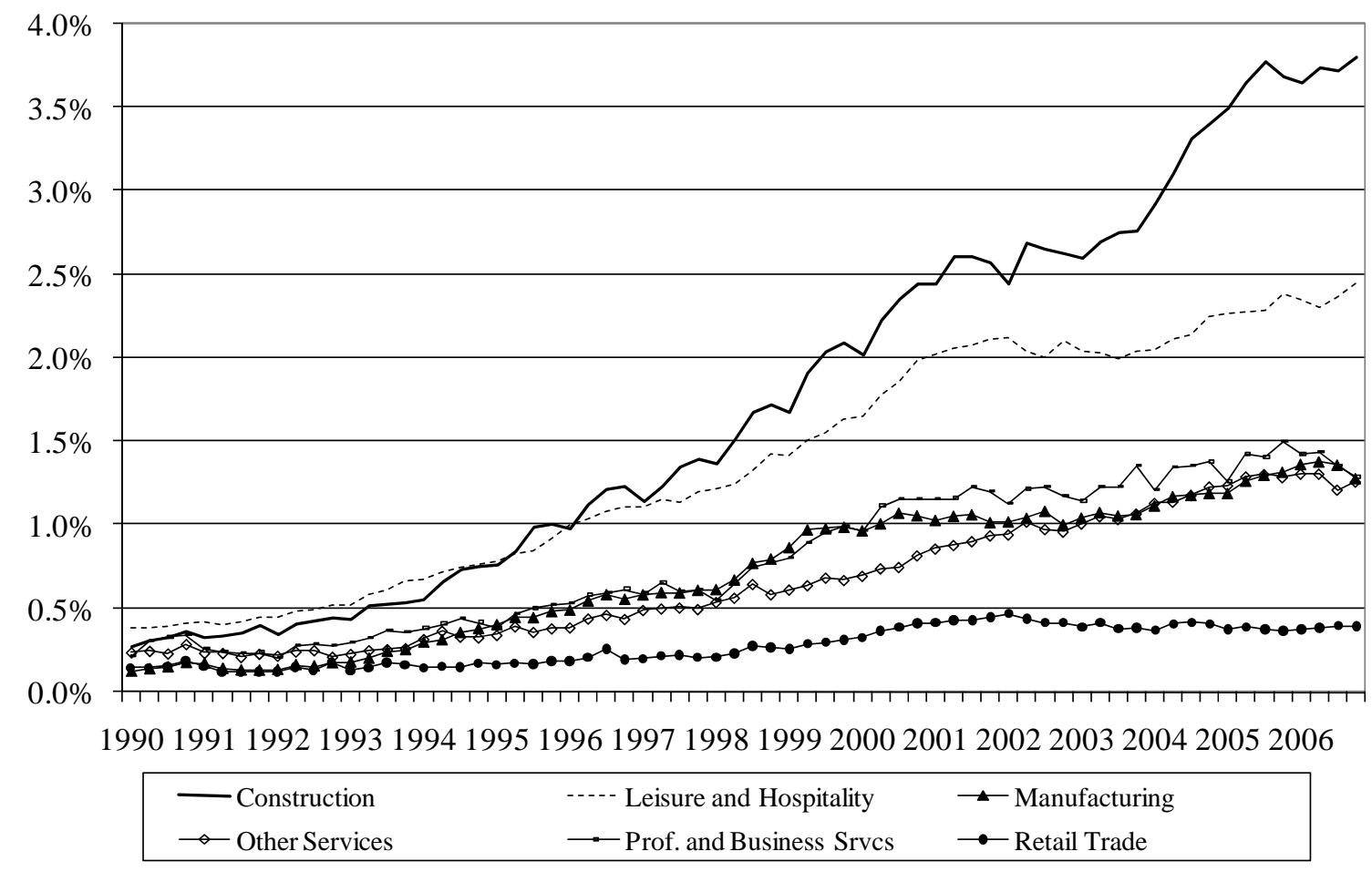


Figure 3.

Percent of firms employing undocumented workers by broad sector, 1990:1-2006:4

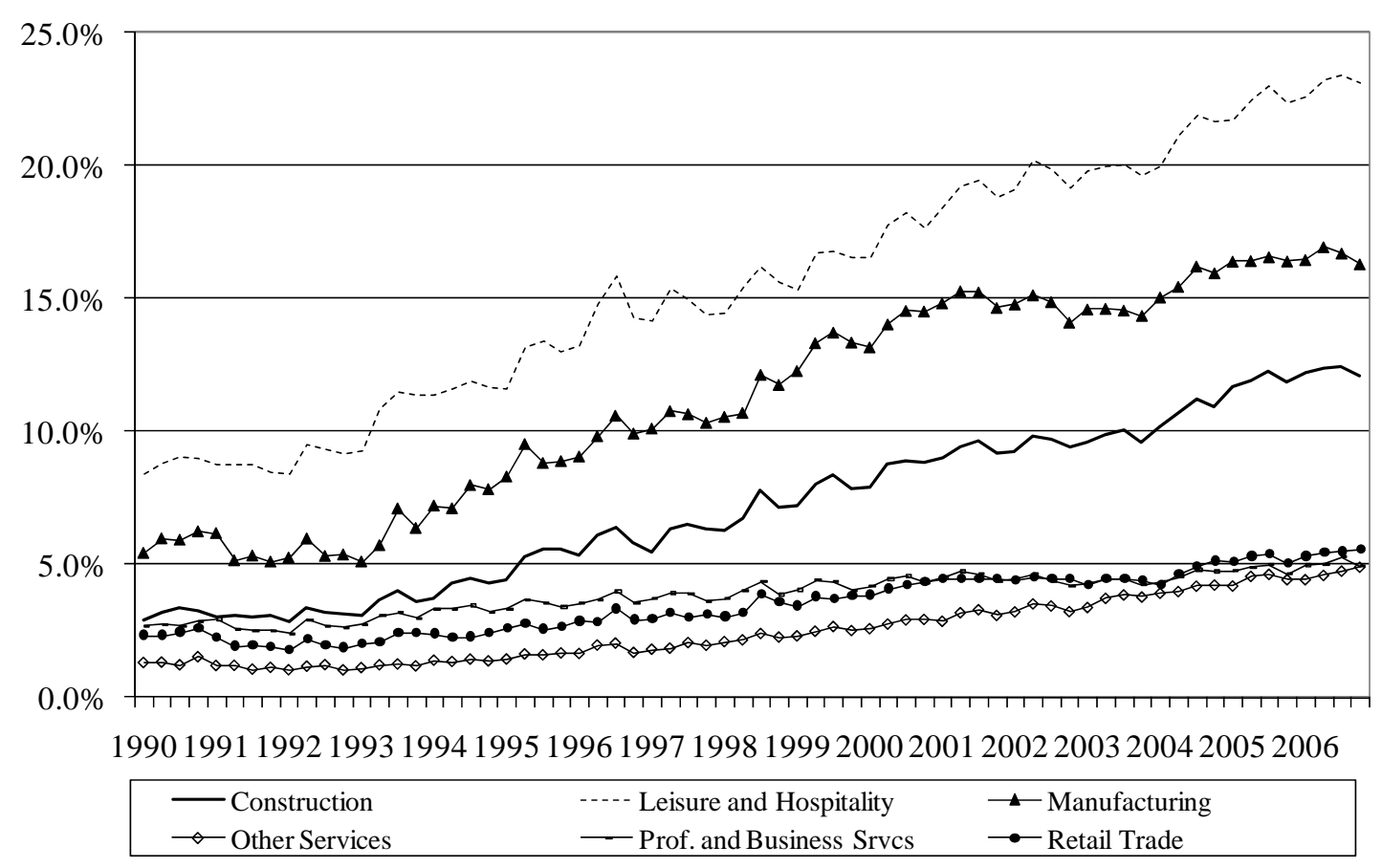

Figure 4.

Percent of firms employing and percent of workers that is undocumented, Agriculture and Natural Resources sector, 1990:1 - 2006:4

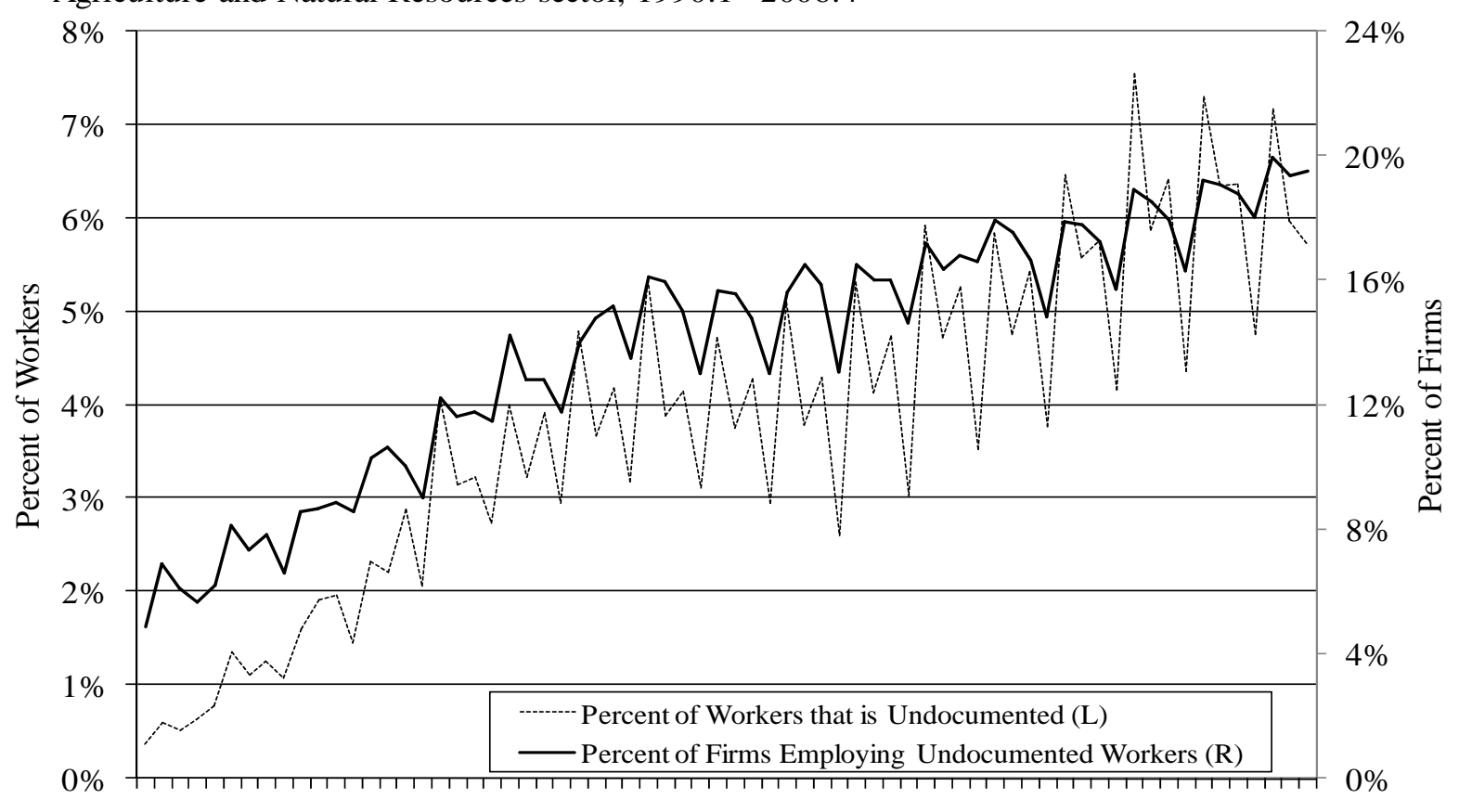


Figure 5. Growth in the earnings suspense file and the total number and percent of workers identified as undocumented in Georgia, 1990-2006.
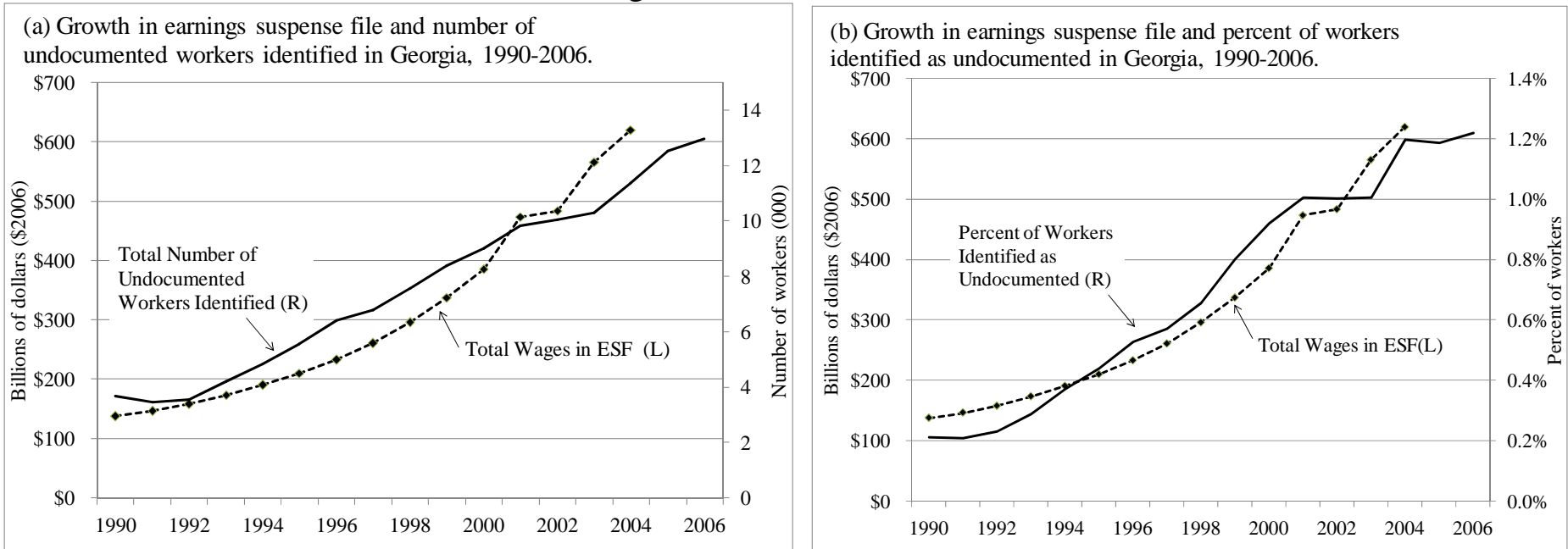

Source: Huse (2002) for estimates 1990-2000, Johnson (2007) for estimates 2001-2004, and authors' calculations. Dollar estimates reflect 2006 values, using the PCE chain-weighted deflator.

Table 1. Correlation between percent of workers identified as undocumented by county and the percent of firms that employ them, with the percent of the population in each county that is Hispanic, African American, and Asian, 2005.

\begin{tabular}{lll}
\hline Percent of Population that is: & $\begin{array}{l}\text { Percent of Undocumented } \\
\text { Workers in County }\end{array}$ & $\begin{array}{l}\text { Percent of Firms Employing } \\
\text { Undocumented Workers } \\
\text { in County }\end{array}$ \\
\hline Hispanic & 0.18 & 0.38 \\
Asian & -0.02 & 0.27 \\
African American & -0.19 & -0.13 \\
\hline
\end{tabular}


Table 2. Select sample means.

Percent of firms employing undocumented workers

Percent of workers that is undocumented

Total Employment

Number of establishments in firm 1.22

Percent of firms exiting

Number of firms in industry

Broad market

Age of firm (number of quarters)

Average worker tenure among

documented (number of quarters)

Average worker tenure among undocumented (num. of quarters)

Percent of county population that is Hispanic ${ }^{\mathrm{a}}$

Percent of county school enrollment that is Hispanic

Employment variability ${ }^{\mathrm{b}}$
(3.50)

$1.77 \%$

\section{1,238}

$(1,592)$

0.662

(0.139)

0.662

(0.138)

1.12

(2.35)

$1.80 \%$

1,254

$(1,609)$

$(1,100)$

0.670

(0.150)

19.11

(5.32)

19.58

(5.07)

(5.31)

10.29

(5.60)

10.43

(5.62)

7.18

(3.97)

3.53

(4.45)

$--$

3.53

(4.45)

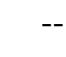

$2.00 \%$

(1.45)

$1.99 \%$

(1.44)

879

$(45,518)$

224

$(12,384)$

382,729

366,156 16,573
$0.98 \%$

(4.87)

24.61

(252.41)

16.25

(109.98)

1.32

(6.08)

1.19

(4.39)

$2.12 \%$

$2.21 \%$

$1.18 \%$

Number of firm-quarter obs.

Notes. Standard deviatio whose SSN has an area number that is too high to be valid or a group number that appears out of sequence. Note when comparing values between 1995 and 2005 that 1990 is the first year in which any firm is observed in the data.

${ }^{\mathrm{a}}$ Statistic not available in 1995.

${ }^{\mathrm{b}}$ Measured as the cumulative variance in total employment. 
Table 3. Bivariate probit estimation results and marginal effects.

Panel (a): Agriculture, Construction, Manufacturing

\begin{tabular}{|c|c|c|c|c|c|c|}
\hline & \multicolumn{2}{|c|}{ Agriculture } & \multicolumn{2}{|c|}{ Construction } & \multicolumn{2}{|c|}{ Manufacturing } \\
\hline Regressors & $\mathrm{P}(U N D O C=1)$ & $\mathrm{P}($ Exit=1) & $\mathrm{P}(U N D O C=1)$ & $\mathrm{P}($ Exit=1) & $\mathrm{P}(U N D O C=1)$ & $\mathrm{P}($ Exit=1) \\
\hline UNDOC & & $\begin{array}{l}-0.227^{*} \\
(0.050) \\
{[-0.00676]^{*}}\end{array}$ & & $\begin{array}{l}-0.209^{*} \\
(0.020) \\
{[-0.00758]^{*}}\end{array}$ & & $\begin{array}{l}-0.163^{*} \\
(0.024) \\
{[-0.00493]^{*}}\end{array}$ \\
\hline IndUNDOC & $\begin{array}{l}6.345^{*} \\
(0.924) \\
{[0.31678]^{*}}\end{array}$ & $\begin{array}{l}-0.638 \\
(0.666) \\
{[0.00075]}\end{array}$ & $\begin{array}{l}6.908^{*} \\
(0.868) \\
{[0.48472]^{*}}\end{array}$ & $\begin{array}{l}0.492 \\
(0.516) \\
{[0.01666]^{*}}\end{array}$ & $\begin{array}{l}7.619 * \\
(0.743) \\
{[0.24958]^{*}}\end{array}$ & $\begin{array}{l}1.290 * \\
(0.462) \\
{[0.01424]^{*}}\end{array}$ \\
\hline BroadMarket & $\begin{array}{l}0.934^{*} \\
(0.301) \\
{[-0.06416]^{*}}\end{array}$ & $\begin{array}{l}-0.382 * \\
(0.149) \\
{[-0.01058]^{*}}\end{array}$ & $\begin{array}{l}0.386^{\wedge} \\
(0.200) \\
{[-0.02438]^{*}}\end{array}$ & $\begin{array}{l}0.262 * \\
(0.095) \\
{[0.00841]^{*}}\end{array}$ & $\begin{array}{l}0.898^{*} \\
(0.137) \\
{[-0.05265]^{*}}\end{array}$ & $\begin{array}{l}0.225^{*} \\
(0.078) \\
{[0.00107]^{*}}\end{array}$ \\
\hline Broad*INDUNDOC & $\begin{array}{l}-5.864 * \\
(1.075)\end{array}$ & $\begin{array}{l}0.771 \\
(0.782)\end{array}$ & $\begin{array}{l}-5.083^{*} \\
(1.381)\end{array}$ & $\begin{array}{l}-0.617 \\
(0.824)\end{array}$ & $\begin{array}{l}-7.338^{*} \\
(0.802)\end{array}$ & $\begin{array}{l}-1.263^{*} \\
(0.505)\end{array}$ \\
\hline 1 Employee & $\begin{array}{l}-1.844 * \\
(0.286) \\
{[-0.16049]^{*}}\end{array}$ & $\begin{array}{l}1.646 * \\
(0.356) \\
{[0.22633]^{*}}\end{array}$ & $\begin{array}{l}-1.111^{*} \\
(0.147) \\
{[-0.09054]^{*}}\end{array}$ & $\begin{array}{l}1.090^{*} \\
(0.126) \\
{[0.10645]^{*}}\end{array}$ & $\begin{array}{l}-1.583 * \\
(0.092) \\
{[-0.13279]^{*}}\end{array}$ & $\begin{array}{l}0.971 * \\
(0.061) \\
{[0.08115]^{*}}\end{array}$ \\
\hline 2 Employees & $\begin{array}{l}-1.586^{*} \\
(0.276) \\
{[-0.15207]^{*}}\end{array}$ & $\begin{array}{l}1.552 * \\
(0.356) \\
{[0.20254]^{*}}\end{array}$ & $\begin{array}{l}-0.835^{*} \\
(0.146) \\
{[-0.07748]^{*}}\end{array}$ & $\begin{array}{l}0.976 * \\
(0.126) \\
{[0.09050]^{*}}\end{array}$ & $\begin{array}{l}-1.358^{*} \\
(0.090) \\
{[-0.12840]^{*}}\end{array}$ & $\begin{array}{l}0.766 * \\
(0.061) \\
{[0.05331]^{*}}\end{array}$ \\
\hline 3-10 Employees & $\begin{array}{l}-0.781 * \\
(0.270) \\
{[-0.13154]^{*}}\end{array}$ & $\begin{array}{l}1.238^{*} \\
(0.354) \\
{[0.08008]^{*}}\end{array}$ & $\begin{array}{l}-0.405^{*} \\
(0.143) \\
{[-0.05286]^{*}}\end{array}$ & $\begin{array}{l}0.759 * \\
(0.125) \\
{[0.04618]^{*}}\end{array}$ & $\begin{array}{l}-0.853 * \\
(0.073) \\
{[-0.12699]^{*}}\end{array}$ & $\begin{array}{l}0.535^{*} \\
(0.057) \\
{[0.02442]^{*}}\end{array}$ \\
\hline 11-100 Employees & $\begin{array}{l}-0.130 \\
(0.264) \\
{[-0.01950]^{*}}\end{array}$ & $\begin{array}{l}0.913^{*} \\
(0.351) \\
{[0.06707]^{*}}\end{array}$ & $\begin{array}{l}0.005 \\
(0.141) \\
{[0.00059]}\end{array}$ & $\begin{array}{l}0.474 * \\
(0.122) \\
{[0.02974]^{*}}\end{array}$ & $\begin{array}{l}-0.230^{*} \\
(0.061) \\
{[-0.03739]^{*}}\end{array}$ & $\begin{array}{l}0.324 * \\
(0.048) \\
{[0.01325]^{*}}\end{array}$ \\
\hline 101-250 Employees & $\begin{array}{l}0.111 \\
(0.275) \\
{[0.01783]^{*}}\end{array}$ & $\begin{array}{l}0.744^{\wedge} \\
(0.356) \\
{[0.05911]^{*}}\end{array}$ & $\begin{array}{l}0.188 \\
(0.137) \\
{[0.02578]^{*}}\end{array}$ & $\begin{array}{l}0.177 \\
(0.130) \\
{[0.01028]^{*}}\end{array}$ & $\begin{array}{l}-0.051 \\
(0.057) \\
{[-0.00877]^{*}}\end{array}$ & $\begin{array}{l}0.124^{*} \\
(0.048) \\
{[0.00447]^{*}}\end{array}$ \\
\hline Wage & $\begin{array}{l}-0.030 \\
(0.014) \\
{[-0.00451]^{*}}\end{array}$ & $\begin{array}{l}-0.011^{*} \\
(0.004) \\
{[-0.00041]^{*}}\end{array}$ & $\begin{array}{l}-0.033^{*} \\
(0.003) \\
{[-0.00378]^{*}}\end{array}$ & $\begin{array}{l}-0.008^{*} \\
(0.001) \\
{[-0.00038]^{*}}\end{array}$ & $\begin{array}{l}-0.064^{*} \\
(0.005) \\
{[-0.00937]^{*}}\end{array}$ & $\begin{array}{l}-0.008^{*} \\
(0.002) \\
{[-0.00044]^{*}}\end{array}$ \\
\hline Wage Squared/100 & $\begin{array}{l}0.007 \\
(0.037) \\
\end{array}$ & $\begin{array}{l}0.010^{*} \\
(0.003)\end{array}$ & $\begin{array}{l}0.020^{*} \\
(0.002)\end{array}$ & $\begin{array}{l}0.005^{*} \\
(0.001) \\
\end{array}$ & $\begin{array}{l}0.042 * \\
(0.005) \\
\end{array}$ & $\begin{array}{l}0.007 * \\
(0.002) \\
\end{array}$ \\
\hline $\begin{array}{l}\text { Proportion of } \\
\text { Documented Workers } \\
\text { Part-time }\end{array}$ & $\begin{array}{l}-0.214^{\wedge} \\
(0.092) \\
{[-0.03289]^{*}}\end{array}$ & $\begin{array}{l}0.198^{*} \\
(0.052) \\
{[0.00608]^{*}}\end{array}$ & $\begin{array}{l}-0.149 * \\
(0.031) \\
{[-0.01871]^{*}}\end{array}$ & $\begin{array}{l}0.182^{*} \\
(0.016) \\
{[0.00717]^{*}}\end{array}$ & $\begin{array}{l}-0.124^{\wedge} \\
(0.054) \\
{[-0.02022]^{*}}\end{array}$ & $\begin{array}{l}0.227^{*} \\
(0.029) \\
{[0.00709]^{*}}\end{array}$ \\
\hline Age & $\begin{array}{l}0.030^{*} \\
(0.005) \\
{[0.00191]^{*}}\end{array}$ & $\begin{array}{l}-0.011^{*} \\
(0.004) \\
{[-0.00008]^{*}}\end{array}$ & $\begin{array}{l}0.015^{*} \\
(0.002) \\
{[0.00085]^{*}}\end{array}$ & $\begin{array}{l}-0.014 * \\
(0.001) \\
{[-0.00034]^{*}}\end{array}$ & $\begin{array}{l}0.034^{*} \\
(0.003) \\
{[0.00169]^{*}}\end{array}$ & $\begin{array}{l}-0.010^{*} \\
(0.002) \\
{[-0.00019]^{*}}\end{array}$ \\
\hline Age Squared/100 & $\begin{array}{l}-0.028^{*} \\
(0.007)\end{array}$ & $\begin{array}{l}0.013^{\wedge} \\
(0.006)\end{array}$ & $\begin{array}{l}-0.013^{*} \\
(0.003)\end{array}$ & $\begin{array}{l}0.011^{*} \\
(0.002)\end{array}$ & $\begin{array}{l}-0.033^{*} \\
(0.004)\end{array}$ & $\begin{array}{l}0.005^{+} \\
(0.003)\end{array}$ \\
\hline Multi-establishment & $\begin{array}{l}-0.235 \\
(0.245) \\
{[-0.03408]^{*}}\end{array}$ & $\begin{array}{l}0.195 \\
(0.172) \\
{[0.01029]^{*}}\end{array}$ & $\begin{array}{l}-0.101 \\
(0.141) \\
{[-0.01208]^{*}}\end{array}$ & $\begin{array}{l}-0.037 \\
(0.107) \\
{[-0.00179]^{*}}\end{array}$ & $\begin{array}{l}0.045 \\
(0.057) \\
{[0.00805]^{*}} \\
\end{array}$ & $\begin{array}{l}-0.133^{*} \\
(0.047) \\
{[-0.00377]^{*}}\end{array}$ \\
\hline $\begin{array}{l}\text { Employment } \\
\text { Churning }\end{array}$ & $\begin{array}{l}0.019 * \\
(0.008) \\
{[0.00287]^{*}}\end{array}$ & $\begin{array}{l}-0.009 \\
(0.006) \\
{[-0.00024]^{*}}\end{array}$ & $\begin{array}{l}0.013^{*} \\
(0.003) \\
{[0.00163]^{*}}\end{array}$ & $\begin{array}{l}-0.002 \\
(0.002) \\
{[-0.00002]^{*}}\end{array}$ & $\begin{array}{l}0.002^{+} \\
(0.001) \\
{[0.00036]^{*}}\end{array}$ & $\begin{array}{l}-0.013^{\wedge} \\
(0.006) \\
{[-0.00041]^{*}}\end{array}$ \\
\hline Log Tenure & $\begin{array}{l}-0.596 * \\
(0.038) \\
{[-0.01451]^{*}}\end{array}$ & $\begin{array}{l}-0.071^{*} \\
(0.024) \\
{[-0.00073]^{*}}\end{array}$ & $\begin{array}{l}-0.322 * \\
(0.015) \\
{[-0.00685]^{*}}\end{array}$ & $\begin{array}{l}-0.066 * \\
(0.008) \\
{[-0.00079]^{*}}\end{array}$ & $\begin{array}{l}-0.440 * \\
(0.022) \\
{[-0.00896]^{*}}\end{array}$ & $\begin{array}{l}-0.018 \\
(0.014) \\
{[-0.00034]^{*}}\end{array}$ \\
\hline Log Employment & $0.133^{*}$ & $0.075^{*}$ & $0.197^{*}$ & $0.087 *$ & $0.107^{*}$ & $0.072 *$ \\
\hline
\end{tabular}




\begin{tabular}{|c|c|c|c|c|c|c|}
\hline Variability & $\begin{array}{l}(0.015) \\
{[0.00354]^{*}}\end{array}$ & $\begin{array}{l}(0.011) \\
{[0.00113] *}\end{array}$ & $\begin{array}{l}(0.008) \\
{[0.00485]^{*}}\end{array}$ & $\begin{array}{l}(0.005) \\
{[0.00198]^{*}}\end{array}$ & $\begin{array}{l}(0.008) \\
{[0.00202]^{*}}\end{array}$ & $\begin{array}{l}(0.005) \\
{[0.00087]^{*}}\end{array}$ \\
\hline Industry Growth & $\begin{array}{l}0.270 * \\
(0.060) \\
{[0.04142]^{*}}\end{array}$ & $\begin{array}{l}-0.055 \\
(0.079) \\
{[-0.00113]^{*}}\end{array}$ & $\begin{array}{l}0.234^{*} \\
(0.053) \\
{[0.02949]^{*}}\end{array}$ & $\begin{array}{l}-0.116^{\wedge} \\
(0.054) \\
{[-0.00417]^{*}}\end{array}$ & $\begin{array}{l}0.068 * \\
(0.027) \\
{[0.01110]^{*}}\end{array}$ & $\begin{array}{l}-0.109 * \\
(0.034) \\
{[-0.00338]^{*}}\end{array}$ \\
\hline $\begin{array}{l}\text { County Sector } \\
\text { Growth }\end{array}$ & $\begin{array}{l}0.070^{+} \\
(0.038) \\
{[0.01078]^{*}}\end{array}$ & $\begin{array}{l}-0.005 \\
(0.049) \\
{[0.00003]}\end{array}$ & $\begin{array}{l}0.199 * \\
(0.034) \\
{[0.02504]^{*}}\end{array}$ & $\begin{array}{l}-0.080^{\wedge} \\
(0.034) \\
{[-0.00273]^{*}}\end{array}$ & $\begin{array}{l}-0.004 \\
(0.028) \\
{[-0.00059]^{*}}\end{array}$ & $\begin{array}{l}-0.034 \\
(0.035) \\
{[-0.00115]^{*}}\end{array}$ \\
\hline $\begin{array}{l}\text { County Population } \\
\text { Growth }\end{array}$ & $\begin{array}{l}0.727 \\
(1.452) \\
{[0.11160]^{*}}\end{array}$ & $\begin{array}{l}1.293 \\
(0.867) \\
{[0.04544]^{*}}\end{array}$ & $\begin{array}{l}3.762 * \\
(0.548) \\
{[0.47325]^{*}}\end{array}$ & $\begin{array}{l}0.324 \\
(0.279) \\
{[0.02488]^{*}}\end{array}$ & $\begin{array}{l}3.610^{*} \\
(0.773) \\
{[0.58678]^{*}}\end{array}$ & $\begin{array}{l}0.424 \\
(0.477) \\
{[0.02614]^{*}}\end{array}$ \\
\hline $\begin{array}{l}\text { Log Per Capita } \\
\text { Income }\end{array}$ & $\begin{array}{l}0.052 \\
(0.245) \\
{[0.00039]^{*}}\end{array}$ & $\begin{array}{l}-0.051 \\
(0.090) \\
{[-0.00008]^{*}}\end{array}$ & $\begin{array}{l}0.175^{*} \\
(0.063) \\
{[0.00080]^{*}}\end{array}$ & $\begin{array}{l}0.061^{*} \\
(0.020) \\
{[0.00012]^{*}}\end{array}$ & $\begin{array}{l}0.255^{*} \\
(0.081) \\
{[0.00162]^{*}}\end{array}$ & $\begin{array}{l}0.089^{*} \\
(0.030) \\
{[0.00015]^{*}}\end{array}$ \\
\hline $\begin{array}{l}\text { Free \& Reduced } \\
\text { Lunch }\end{array}$ & $\begin{array}{l}-0.139 \\
(0.199) \\
{[-0.02138]^{*}}\end{array}$ & $\begin{array}{l}-0.053 \\
(0.108) \\
{[-0.00217]^{*}}\end{array}$ & $\begin{array}{l}-0.209 * \\
(0.071) \\
{[-0.02629]^{*}}\end{array}$ & $\begin{array}{l}0.142 * \\
(0.034) \\
{[0.00534]^{*}}\end{array}$ & $\begin{array}{l}-0.112 \\
(0.095) \\
{[-0.01812]^{*}}\end{array}$ & $\begin{array}{l}0.052 \\
(0.054) \\
{[0.00134]^{*}}\end{array}$ \\
\hline $\begin{array}{l}\text { Log Population } \\
\text { Density } \\
(P O P D E N)\end{array}$ & $\begin{array}{l}0.007 \\
(0.038) \\
{[0.02438]^{*}}\end{array}$ & & $\begin{array}{l}0.013 \\
(0.012) \\
{[0.00720]^{*}}\end{array}$ & & $\begin{array}{l}0.071^{*} \\
(0.016) \\
{[0.07078]^{*}}\end{array}$ & \\
\hline $\begin{array}{l}\text { Hispanic Enrollment } \\
(\text { HISPENROL) }\end{array}$ & $\begin{array}{l}1.674^{\wedge} \\
(0.698) \\
{[0.25710]^{*}}\end{array}$ & & $\begin{array}{l}1.190 * \\
(0.210) \\
{[0.14964]^{*}}\end{array}$ & & $\begin{array}{l}0.911^{*} \\
(0.302) \\
{[0.14808]^{*}}\end{array}$ & \\
\hline $\begin{array}{l}\text { County UNDOC } \\
\left(C S \_U N D O C\right)\end{array}$ & $\begin{array}{l}0.766^{*} \\
(0.147) \\
{[0.11770]^{*}}\end{array}$ & & $\begin{array}{l}2.658^{*} \\
(0.257) \\
{[0.33432]^{*}}\end{array}$ & & $\begin{array}{l}2.093^{*} \\
(0.165) \\
{[0.34026]^{*}}\end{array}$ & \\
\hline$\rho$ & \multicolumn{2}{|c|}{0.000} & \multicolumn{2}{|c|}{0.000} & \multicolumn{2}{|c|}{0.000} \\
\hline Firms & \multirow{2}{*}{\multicolumn{2}{|c|}{$\begin{array}{c}3,314 \\
72047\end{array}$}} & \multirow{2}{*}{\multicolumn{2}{|c|}{$\begin{array}{c}29,378 \\
530768\end{array}$}} & \multicolumn{2}{|c|}{11,665} \\
\hline Observations & & & & & \multicolumn{2}{|c|}{271,434} \\
\hline
\end{tabular}

Panel (b): Transport \& Utilities, Wholesale Trade, Retail Trade

\begin{tabular}{|l|l|l|l|l|l|l|}
\hline & \multicolumn{2}{|c|}{ Transport \& Utilities } & \multicolumn{2}{c|}{ Wholesale Trade } & \multicolumn{2}{c|}{ Retail Trade } \\
\hline Regressors & $\mathrm{P}(U N D O C=1)$ & $\mathrm{P}($ Exit=1) & $\mathrm{P}($ UNDOC=1) & $\mathrm{P}($ Exit=1) & $\mathrm{P}($ UNDOC=1) & $\mathrm{P}($ Exit=1) \\
\hline UNDOC & & $-0.126^{*}$ & & $-0.156^{*}$ & & $-0.153^{*}$ \\
& & $(0.046)$ & & $(0.034)$ & & $(0.026)$ \\
& & {$[-0.00593]^{*}$} & & {$[-0.00584]^{*}$} & & {$[-0.00581]^{*}$} \\
\hline IndUNDOC & $12.766^{*}$ & -0.924 & $6.660^{*}$ & 1.308 & $5.650^{*}$ & -0.140 \\
& $(3.072)$ & $(1.595)$ & $(2.259)$ & $(1.261)$ & $(0.876)$ & $(0.458)$ \\
& {$[0.38416]^{*}$} & {$[-0.01111]^{*}$} & {$[0.30496]^{*}$} & {$[0.00953]^{*}$} & {$[0.19462]^{*}$} & {$[0.00524]^{*}$} \\
\hline BroadMarket & 0.235 & -0.101 & -0.014 & $0.425^{*}$ & 0.020 & $0.093^{+}$ \\
& $(0.177)$ & $(0.073)$ & $(0.204)$ & $(0.085)$ & $(0.121)$ & $(0.049)$ \\
& {$[-0.03570]^{*}$} & {$[-0.00485]^{*}$} & {$[-0.00908]^{*}$} & {$[0.01627]^{*}$} & {$[-0.01790]^{*}$} & {$[0.00402]^{*}$} \\
\hline Broad*INDUNDOC & $-11.524^{*}$ & 0.752 & -2.468 & -1.625 & $-5.349^{*}$ & 0.269 \\
& $(3.419)$ & $(1.846)$ & $(2.964)$ & $(1.648)$ & $(1.077)$ & $(0.599)$ \\
\hline 1 Employee & $-1.276^{*}$ & 1.073 & $-1.424^{*}$ & $1.211^{*}$ & $-1.384^{*}$ & $1.119^{*}$ \\
& $(0.152)$ & $(0.120)$ & $(0.120)$ & $(0.119)$ & $(0.081)$ & $(0.080)$ \\
& {$[-0.05296]^{*}$} & {$[0.11620]^{*}$} & {$[-0.04619]^{*}$} & {$[0.11647]^{*}$} & {$[-0.05232]^{*}$} & {$[0.11623]^{*}$} \\
\hline 2 Employees & $-1.058^{*}$ & $0.914^{*}$ & $-1.134^{*}$ & $1.010^{*}$ & $-1.148^{*}$ & $0.912^{*}$ \\
& $(0.151)$ & $(0.120)$ & $(0.123)$ & $(0.119)$ & $(0.080)$ & $(0.079)$ \\
& {$[-0.04836]^{*}$} & {$[0.09612]^{*}$} & {$[-0.04152]^{*}$} & {$[0.09756]^{*}$} & {$[-0.05122]^{*}$} & {$[0.08162]^{*}$} \\
\hline 3-10 Employees & $-0.702^{*}$ & $0.761^{*}$ & $-0.693^{*}$ & $0.778^{*}$ & $-0.828^{*}$ & $0.729^{*}$ \\
& $(0.135)$ & $(0.116)$ & $(0.110)$ & $(0.117)$ & $(0.075)$ & $(0.077)$ \\
& {$[-0.05122]^{*}$} & {$[0.05876]^{*}$} & {$[-0.04510]^{*}$} & {$[0.05244]^{*}$} & {$[-0.06834]^{*}$} & {$[0.04242]^{*}$} \\
\hline 11-100 Employees & $-0.281^{*}$ & $0.481^{*}$ & $-0.289^{*}$ & $0.535^{*}$ & $-0.534^{*}$ & $0.476^{*}$ \\
& & & & & &
\end{tabular}




\begin{tabular}{|c|c|c|c|c|c|c|}
\hline & $\begin{array}{l}(0.111) \\
{[-0.02208]^{*}}\end{array}$ & $\begin{array}{l}(0.107) \\
{[0.03502]^{*}}\end{array}$ & $\begin{array}{l}(0.102) \\
{[-0.01845]^{*}}\end{array}$ & $\begin{array}{l}(0.113) \\
{[0.03536]^{*}}\end{array}$ & $\begin{array}{l}(0.067) \\
{[-0.03731]^{*}}\end{array}$ & $\begin{array}{l}(0.072) \\
{[0.03049]^{*}}\end{array}$ \\
\hline 101-250 Employees & $\begin{array}{l}-0.126 \\
(0.100) \\
{[-0.01086]^{*}}\end{array}$ & $\begin{array}{l}0.245^{\wedge} \\
(0.110) \\
{[0.01703]^{*}}\end{array}$ & $\begin{array}{l}-0.096 \\
(0.099) \\
{[-0.00687]^{*}}\end{array}$ & $\begin{array}{l}0.186 \\
(0.117) \\
{[0.01097]^{*}}\end{array}$ & $\begin{array}{l}-0.381 * \\
(0.064) \\
{[-0.02871]^{*}}\end{array}$ & $\begin{array}{l}0.239^{*} \\
(0.074) \\
{[0.01488]^{*}}\end{array}$ \\
\hline Wage & $\begin{array}{l}-0.033^{*} \\
(0.008) \\
{[-0.00229]^{*}}\end{array}$ & $\begin{array}{l}-0.009 * \\
(0.003) \\
{[-0.00047]^{*}}\end{array}$ & $\begin{array}{l}-0.046 * \\
(0.003) \\
{[-0.00267]^{*}}\end{array}$ & $\begin{array}{l}-0.000 \\
(0.001) \\
{[-0.00007]^{*}}\end{array}$ & $\begin{array}{l}-0.022 * \\
(0.006) \\
{[-0.00157]^{*}}\end{array}$ & $\begin{array}{l}-0.007^{*} \\
(0.002) \\
{[-0.00033]^{*}}\end{array}$ \\
\hline Wage Squared/100 & $\begin{array}{l}0.029 * \\
(0.006)\end{array}$ & $\begin{array}{l}0.010^{*} \\
(0.003)\end{array}$ & $\begin{array}{l}0.025^{*} \\
(0.002)\end{array}$ & $\begin{array}{l}0.000 \\
(0.001)\end{array}$ & $\begin{array}{l}-0.001 \\
(0.018)\end{array}$ & $\begin{array}{l}0.007^{*} \\
(0.001)\end{array}$ \\
\hline $\begin{array}{l}\text { Proportion of } \\
\text { Documented Workers } \\
\text { Part-time }\end{array}$ & $\begin{array}{l}0.130 \\
(0.081) \\
{[0.01011]^{*}}\end{array}$ & $\begin{array}{l}0.068 \wedge \\
(0.031) \\
{[0.00389]^{*}}\end{array}$ & $\begin{array}{l}0.056 \\
(0.053) \\
{[0.00360]^{*}} \\
\end{array}$ & $\begin{array}{l}0.110^{*} \\
(0.021) \\
{[0.00480]^{*}}\end{array}$ & $\begin{array}{l}-0.226^{*} \\
(0.044) \\
{[-0.01620]^{*}}\end{array}$ & $\begin{array}{l}0.158^{*} \\
(0.014) \\
{[0.00643]^{*}}\end{array}$ \\
\hline Age & $\begin{array}{l}0.018^{*} \\
(0.005) \\
{[0.00048]^{*}}\end{array}$ & $\begin{array}{l}-0.008^{*} \\
(0.002) \\
{[-0.00024]^{*}}\end{array}$ & $\begin{array}{l}0.019 * \\
(0.003) \\
{[0.00016]^{*}}\end{array}$ & $\begin{array}{l}-0.007 * \\
(0.002) \\
{[-0.00020]^{*}}\end{array}$ & $\begin{array}{l}0.011^{*} \\
(0.002) \\
{[0.00010]^{*}}\end{array}$ & $\begin{array}{l}-0.010^{*} \\
(0.001) \\
{[-0.00021]^{*}}\end{array}$ \\
\hline Age Squared/100 & $\begin{array}{l}-0.019 * \\
(0.007)\end{array}$ & $\begin{array}{l}0.007^{+} \\
(0.004)\end{array}$ & $\begin{array}{l}-0.024^{*} \\
(0.004)\end{array}$ & $\begin{array}{l}0.005^{\wedge} \\
(0.002)\end{array}$ & $\begin{array}{l}-0.014^{*} \\
(0.003)\end{array}$ & $\begin{array}{l}0.009 * \\
(0.002)\end{array}$ \\
\hline Multi-establishment & $\begin{array}{l}0.006 \\
(0.088) \\
{[0.00052]}\end{array}$ & $\begin{array}{l}-0.148^{+} \\
(0.077) \\
{[-0.00736]^{*}}\end{array}$ & $\begin{array}{l}0.033 \\
(0.078) \\
{[0.00256]^{*}}\end{array}$ & $\begin{array}{l}-0.084 \\
(0.063) \\
{[-0.00392]^{*}}\end{array}$ & $\begin{array}{l}0.060 \\
(0.044) \\
{[0.00572]^{*}}\end{array}$ & $\begin{array}{l}-0.037 \\
(0.036) \\
{[-0.00183]^{*}}\end{array}$ \\
\hline $\begin{array}{l}\text { Employment } \\
\text { Churning }\end{array}$ & $\begin{array}{l}-0.000 \\
(0.001) \\
{[-0.00002]^{*}}\end{array}$ & $\begin{array}{l}-0.006^{\wedge} \\
(0.003) \\
{[-0.00034]^{*}}\end{array}$ & $\begin{array}{l}0.019 * \\
(0.003) \\
{[0.00118]^{*}}\end{array}$ & $\begin{array}{l}-0.009^{+} \\
(0.005) \\
{[-0.00036]^{*}}\end{array}$ & $\begin{array}{l}0.009^{*} \\
(0.003) \\
{[0.00067]^{*}}\end{array}$ & $\begin{array}{l}-0.004 \\
(0.003) \\
{[-0.00015]^{*}}\end{array}$ \\
\hline Log Tenure & $\begin{array}{l}-0.303^{*} \\
(0.033) \\
{[-0.00419]^{*}}\end{array}$ & $\begin{array}{l}-0.120^{*} \\
(0.014) \\
{[-0.00155]^{*}}\end{array}$ & $\begin{array}{l}-0.271^{*} \\
(0.025) \\
{[-0.00239]^{*}}\end{array}$ & $\begin{array}{l}-0.082 * \\
(0.009) \\
{[-0.00065]^{*}}\end{array}$ & $\begin{array}{l}-0.218^{*} \\
(0.017) \\
{[-0.00265]^{*}}\end{array}$ & $\begin{array}{l}-0.060 * \\
(0.007) \\
{[-0.00059]^{*}}\end{array}$ \\
\hline $\begin{array}{l}\text { Log Employment } \\
\text { Variability }\end{array}$ & $\begin{array}{l}0.110^{*} \\
(0.015) \\
{[0.00124]^{*}}\end{array}$ & $\begin{array}{l}0.064^{*} \\
(0.007) \\
{[0.00173]^{*}}\end{array}$ & $\begin{array}{l}0.121^{*} \\
(0.010) \\
{[0.00153]^{*}}\end{array}$ & $\begin{array}{l}0.071^{*} \\
(0.005) \\
{[0.00186]^{*}}\end{array}$ & $\begin{array}{l}0.146^{*} \\
(0.007) \\
{[0.00234]^{*}}\end{array}$ & $\begin{array}{l}0.056^{*} \\
(0.005) \\
{[0.00133]^{*}}\end{array}$ \\
\hline Industry Growth & $\begin{array}{l}0.169^{\wedge} \\
(0.079) \\
{[0.01315]^{*}}\end{array}$ & $\begin{array}{l}-0.099^{+} \\
(0.060) \\
{[-0.00475]^{*}}\end{array}$ & $\begin{array}{l}0.108^{\wedge} \\
(0.053) \\
{[0.00689]^{*}}\end{array}$ & $\begin{array}{l}-0.116^{\wedge} \\
(0.049) \\
{[-0.00486]^{*}}\end{array}$ & $\begin{array}{l}0.046 \\
(0.051) \\
{[0.00329]^{*}}\end{array}$ & $\begin{array}{l}-0.138^{*} \\
(0.041) \\
{[-0.00592]^{*}}\end{array}$ \\
\hline $\begin{array}{l}\text { County Sector } \\
\text { Growth }\end{array}$ & $\begin{array}{l}0.059^{+} \\
(0.036) \\
{[0.00457]^{*}}\end{array}$ & $\begin{array}{l}-0.008 \\
(0.030) \\
{[-0.00026]^{*}}\end{array}$ & $\begin{array}{l}-0.013 \\
(0.037) \\
{[-0.00084]^{*}}\end{array}$ & $\begin{array}{l}-0.050 \\
(0.032) \\
{[-0.00219]^{*}}\end{array}$ & $\begin{array}{l}0.007 \\
(0.018) \\
{[0.00051]^{*}}\end{array}$ & $\begin{array}{l}-0.023 \\
(0.017) \\
{[-0.00097]^{*}}\end{array}$ \\
\hline $\begin{array}{l}\text { County Population } \\
\text { Growth }\end{array}$ & $\begin{array}{l}2.901^{\wedge} \\
(1.237) \\
{[0.22524]^{*}}\end{array}$ & $\begin{array}{l}-0.498 \\
(0.535) \\
{[-0.01890]^{*}}\end{array}$ & $\begin{array}{l}3.084^{*} \\
(0.965) \\
{[0.19652]^{*}}\end{array}$ & $\begin{array}{l}-0.470 \\
(0.377) \\
{[-0.01605]^{*}}\end{array}$ & $\begin{array}{l}1.135^{+} \\
(0.652) \\
{[0.08154]^{*}}\end{array}$ & $\begin{array}{l}0.290 \\
(0.303) \\
{[0.01458]^{*}}\end{array}$ \\
\hline $\begin{array}{l}\text { Log Per Capita } \\
\text { Income }\end{array}$ & $\begin{array}{l}0.081 \\
(0.100) \\
{[0.00024]^{*}}\end{array}$ & $\begin{array}{l}0.001 \\
(0.033) \\
{[0.00001]^{*}}\end{array}$ & $\begin{array}{l}0.129 \\
(0.081) \\
{[0.00029]^{*}}\end{array}$ & $\begin{array}{l}0.058^{*} \\
(0.021) \\
{[0.00009]^{*}}\end{array}$ & $\begin{array}{l}0.278^{*} \\
(0.043) \\
{[0.00074]^{*}}\end{array}$ & $\begin{array}{l}0.071^{*} \\
(0.017) \\
{[0.00014]^{*}}\end{array}$ \\
\hline $\begin{array}{l}\text { Free \& Reduced } \\
\text { Lunch }\end{array}$ & $\begin{array}{l}-0.106 \\
(0.155) \\
{[0.00218]^{*}}\end{array}$ & $\begin{array}{l}0.047 \\
(0.060) \\
{[-0.00044]^{*}}\end{array}$ & $\begin{array}{l}0.040 \\
(0.114) \\
{[0.00257]^{*}}\end{array}$ & $\begin{array}{l}0.045 \\
(0.037) \\
{[0.00200]^{*}}\end{array}$ & $\begin{array}{l}-0.053 \\
(0.073) \\
{[-0.00383]^{*}}\end{array}$ & $\begin{array}{l}-0.006 \\
(0.033) \\
{[-0.00035]^{*}}\end{array}$ \\
\hline $\begin{array}{l}\text { Log Population } \\
\text { Density } \\
(P O P D E N)\end{array}$ & $\begin{array}{l}-0.001 \\
(0.020) \\
{[-0.00044]}\end{array}$ & & $\begin{array}{l}0.018 \\
(0.018) \\
{[0.00462]^{*}}\end{array}$ & & & \\
\hline $\begin{array}{l}\text { Hispanic Enrollment } \\
\text { (HISPENROL) }\end{array}$ & & & $\begin{array}{l}1.425^{*} \\
(0.318) \\
{[0.09080]^{*}}\end{array}$ & & $\begin{array}{l}1.675^{*} \\
(0.222) \\
{[0.12031]^{*}}\end{array}$ & \\
\hline $\begin{array}{l}\text { County UNDOC } \\
\left(C S \_U N D O C\right)\end{array}$ & $\begin{array}{l}1.095 * \\
(0.324) \\
{[0.08506]^{*}}\end{array}$ & & $\begin{array}{l}0.932 * \\
(0.310) \\
{[0.05937]^{*}} \\
\end{array}$ & & $\begin{array}{l}2.775^{*} \\
(0.412) \\
{[0.19933]^{*}} \\
\end{array}$ & \\
\hline$\rho$ & \multicolumn{2}{|c|}{0.000} & \multicolumn{2}{|c|}{0.000} & \multicolumn{2}{|c|}{0.000} \\
\hline
\end{tabular}




\begin{tabular}{|l|c|c|c|}
\hline Firms & 8,224 & 22,439 & 31,034 \\
\hline Observations & 139,751 & 435,685 & 620,336 \\
\hline
\end{tabular}

Panel (c): Financial Services, Information, Profession \& Business Services

\begin{tabular}{|c|c|c|c|c|c|c|}
\hline & \multicolumn{2}{|c|}{ Financial Services } & \multicolumn{2}{|c|}{ Information } & \multicolumn{2}{|c|}{ Professional \& Business Srvcs } \\
\hline Regressors & $\mathrm{P}(U N D O C=1)$ & $\mathrm{P}($ Exit=1) & $\mathrm{P}(U N D O C=1)$ & $\mathrm{P}($ Exit=1) & $\mathrm{P}(U N D O C=1)$ & $\mathrm{P}($ Exit=1) \\
\hline UNDOC & & $\begin{array}{l}-0.175^{*} \\
(0.042) \\
{[-0.00632]^{*}}\end{array}$ & & $\begin{array}{l}-0.219 * \\
(0.077) \\
{[-0.00946]^{*}}\end{array}$ & & $\begin{array}{l}-0.207 * \\
(0.021) \\
{[-0.00767]^{*}}\end{array}$ \\
\hline IndUNDOC & $\begin{array}{l}13.892 * \\
(3.018) \\
{[0.21576]^{*}}\end{array}$ & $\begin{array}{l}\text { 12.586* } \\
(1.837) \\
{[0.11117]^{*}}\end{array}$ & $\begin{array}{l}-4.543 \\
(4.649) \\
{[-0.02934]^{*}}\end{array}$ & $\begin{array}{l}2.709 \\
(3.425) \\
{[-0.00871]^{*}}\end{array}$ & $\begin{array}{l}24.558^{*} \\
(0.864) \\
{[0.26143]^{*}}\end{array}$ & $\begin{array}{l}1.990^{*} \\
(0.436) \\
{[0.01533]^{*}}\end{array}$ \\
\hline BroadMarket & $\begin{array}{l}0.377^{*} \\
(0.142) \\
{[0.00218]^{+}}\end{array}$ & $\begin{array}{l}0.339^{*} \\
(0.075) \\
{[0.00282]^{*}}\end{array}$ & $\begin{array}{l}-0.642 \\
(0.396) \\
{[-0.02561]^{*}}\end{array}$ & $\begin{array}{l}0.176 \\
(0.207) \\
{[0.00257]^{*}}\end{array}$ & $\begin{array}{l}0.343^{*} \\
(0.112) \\
{[-0.18237]^{*}}\end{array}$ & $\begin{array}{l}0.889 * \\
(0.044) \\
{[0.02905]^{*}}\end{array}$ \\
\hline 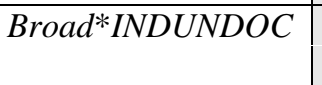 & $\begin{array}{l}-12.349 * \\
(3.370)\end{array}$ & $\begin{array}{l}-14.749 * \\
(2.415)\end{array}$ & $\begin{array}{l}5.494 \\
(5.358)\end{array}$ & $\begin{array}{l}-3.708 \\
(4.054)\end{array}$ & $\begin{array}{l}-29.449 * \\
(1.227)\end{array}$ & $\begin{array}{l}-2.410^{*} \\
(0.624)\end{array}$ \\
\hline 1 Employee & $\begin{array}{l}-1.669 * \\
(0.120) \\
{[-0.03993]^{*}}\end{array}$ & $\begin{array}{l}0.994^{*} \\
(0.083) \\
{[0.08293] *}\end{array}$ & $\begin{array}{l}-1.660^{*} \\
(0.205) \\
{[-0.04851]^{*}}\end{array}$ & $\begin{array}{l}0.858^{*} \\
(0.120) \\
{[0.06670]^{*}}\end{array}$ & $\begin{array}{l}-1.644^{*} \\
(0.069) \\
{[-0.06601]^{*}}\end{array}$ & $\begin{array}{l}0.982 * \\
(0.056) \\
{[0.08147]^{*}}\end{array}$ \\
\hline 2 Employees & $\begin{array}{l}-1.310^{*} \\
(0.120) \\
{[-0.03427]^{*}}\end{array}$ & $\begin{array}{l}0.809^{*} \\
(0.082) \\
{[0.06480]^{*}}\end{array}$ & $\begin{array}{l}-1.445^{*} \\
(0.188) \\
{[-0.04520]^{*}}\end{array}$ & $\begin{array}{l}0.734^{*} \\
(0.120) \\
{[0.06827]^{*}}\end{array}$ & $\begin{array}{l}-1.355^{*} \\
(0.069) \\
{[-0.05793]^{*}}\end{array}$ & $\begin{array}{l}0.816 * \\
(0.056) \\
{[0.06819]^{*}}\end{array}$ \\
\hline 3-10 Employees & $\begin{array}{l}-0.914 * \\
(0.113) \\
{[-0.04564]^{*}}\end{array}$ & $\begin{array}{l}0.652^{*} \\
(0.080) \\
{[0.03966]^{*}}\end{array}$ & $\begin{array}{l}-1.103^{*} \\
(0.167) \\
{[-0.06484]^{*}}\end{array}$ & $\begin{array}{l}0.525^{*} \\
(0.113) \\
{[0.03586]^{*}}\end{array}$ & $\begin{array}{l}-0.907 * \\
(0.062) \\
{[-0.06439]^{*}}\end{array}$ & $\begin{array}{l}0.630 * \\
(0.054) \\
{[0.03969]^{*}}\end{array}$ \\
\hline 11-100 Employees & $\begin{array}{l}-0.582 * \\
(0.098) \\
{[-0.02260]^{*}}\end{array}$ & $\begin{array}{l}0.422 * \\
(0.072) \\
{[0.02552]^{*}}\end{array}$ & $\begin{array}{l}-0.569 * \\
(0.139) \\
{[-0.03784]^{*}}\end{array}$ & $\begin{array}{l}0.409^{*} \\
(0.098) \\
{[0.02728]^{*}}\end{array}$ & $\begin{array}{l}-0.497^{*} \\
(0.054) \\
{[-0.03196]^{*}}\end{array}$ & $\begin{array}{l}0.378^{*} \\
(0.049) \\
{[0.02281]^{*}}\end{array}$ \\
\hline 101-250 Employees & $\begin{array}{l}-0.378 * \\
(0.090) \\
{[-0.01687]^{*}}\end{array}$ & $\begin{array}{l}0.163^{\wedge} \\
(0.077) \\
{[0.00930]^{*}}\end{array}$ & $\begin{array}{l}-0.219^{+} \\
(0.119) \\
{[-0.01823]^{*}}\end{array}$ & $\begin{array}{l}0.222^{\wedge} \\
(0.097) \\
{[0.01404]^{*}}\end{array}$ & $\begin{array}{l}-0.302 * \\
(0.052) \\
{[-0.02099]^{*}}\end{array}$ & $\begin{array}{l}0.136^{*} \\
(0.051) \\
{[0.00761]^{*}}\end{array}$ \\
\hline Wage & $\begin{array}{l}-0.032 * \\
(0.003) \\
{[-0.00118]^{*}}\end{array}$ & $\begin{array}{l}0.001 \\
(0.001) \\
{[0.00001]^{\wedge}}\end{array}$ & $\begin{array}{l}-0.032 * \\
(0.007) \\
{[-0.00179]^{*}}\end{array}$ & $\begin{array}{l}0.006^{*} \\
(0.002) \\
{[0.00017]^{*}}\end{array}$ & $\begin{array}{l}-0.034^{*} \\
(0.003) \\
{[-0.00207]^{*}}\end{array}$ & $\begin{array}{l}0.001 \\
(0.001) \\
{[-0.00004]^{*}}\end{array}$ \\
\hline Wage Squared/100 & $\begin{array}{l}0.018^{*} \\
(0.002)\end{array}$ & $\begin{array}{l}-0.000 \\
(-0.001)\end{array}$ & $\begin{array}{l}0.016^{*} \\
(0.003)\end{array}$ & $\begin{array}{l}-0.006 * \\
(0.002)\end{array}$ & $\begin{array}{l}0.019^{*} \\
(0.001)\end{array}$ & $\begin{array}{l}-0.009 * \\
(0.002)\end{array}$ \\
\hline $\begin{array}{l}\text { Proportion of } \\
\text { Documented Workers } \\
\text { Part-time }\end{array}$ & $\begin{array}{l}0.021 \\
(0.053) \\
{[0.00083]^{*}}\end{array}$ & $\begin{array}{l}0.159^{*} \\
(0.017) \\
{[0.00679]^{*}}\end{array}$ & $\begin{array}{l}0.257^{\wedge} \\
(0.111) \\
{[0.01601]^{*}}\end{array}$ & $\begin{array}{l}0.145^{*} \\
(0.048) \\
{[0.00806]^{*}}\end{array}$ & $\begin{array}{l}-0.128 * \\
(0.034) \\
{[-0.00846]^{*}}\end{array}$ & $\begin{array}{l}0.146^{*} \\
(0.012) \\
{[0.00620]^{*}}\end{array}$ \\
\hline Age & $\begin{array}{l}0.009^{\wedge} \\
(0.004) \\
{[0.00010]^{*}}\end{array}$ & $\begin{array}{l}-0.009^{*} \\
(0.002) \\
{[-0.00023]^{*}}\end{array}$ & $\begin{array}{l}0.022^{*} \\
(0.007) \\
{[0.00045]^{*}}\end{array}$ & $\begin{array}{l}-0.003 \\
(0.004) \\
{[-0.00022]^{*}}\end{array}$ & $\begin{array}{l}0.010^{*} \\
(0.002) \\
{[0.00029]^{*}}\end{array}$ & $\begin{array}{l}-0.013^{*} \\
(0.001) \\
{[-0.00036]^{*}}\end{array}$ \\
\hline Age Squared/100 & $\begin{array}{l}-0.010^{+} \\
(0.005)\end{array}$ & $\begin{array}{l}0.006^{*} \\
(0.002)\end{array}$ & $\begin{array}{l}-0.024^{\wedge} \\
(0.010)\end{array}$ & $\begin{array}{l}-0.004 \\
(0.006)\end{array}$ & $\begin{array}{l}-0.010^{*} \\
(0.003)\end{array}$ & $\begin{array}{l}0.009 * \\
(0.002)\end{array}$ \\
\hline Multi-establishment & $\begin{array}{l}-0.073 \\
(0.066) \\
{[-0.00393]^{*}}\end{array}$ & $\begin{array}{l}-0.028 \\
(0.040) \\
{[-0.00136]^{*}}\end{array}$ & $\begin{array}{l}0.126 \\
(0.116) \\
{[0.01236]^{*}}\end{array}$ & $\begin{array}{l}0.067 \\
(0.074) \\
{[0.00371]^{*}}\end{array}$ & $\begin{array}{l}0.081 \\
(0.052) \\
{[0.00666]^{*}}\end{array}$ & $\begin{array}{l}-0.083^{+} \\
(0.044) \\
{[-0.00381]^{*}}\end{array}$ \\
\hline $\begin{array}{l}\text { Employment } \\
\text { Churning }\end{array}$ & $\begin{array}{l}0.016^{*} \\
(0.003) \\
{[0.00066]^{*}}\end{array}$ & $\begin{array}{l}-0.009^{+} \\
(0.005) \\
{[-0.00035]^{*}}\end{array}$ & $\begin{array}{l}0.006^{+} \\
(0.004) \\
{[0.00036]^{*}}\end{array}$ & $\begin{array}{l}-0.002 \\
(0.003) \\
{[-0.00009]^{*}}\end{array}$ & $\begin{array}{l}0.010^{*} \\
(0.003) \\
{[0.00066]^{*}}\end{array}$ & $\begin{array}{l}-0.001 \\
(0.002) \\
{[-0.00000]^{*}}\end{array}$ \\
\hline Log Tenure & $\begin{array}{l}-0.163 * \\
(0.027) \\
{[-0.00110]^{*}}\end{array}$ & $\begin{array}{l}-0.072 * \\
(0.008) \\
{[-0.00062]^{*}}\end{array}$ & $\begin{array}{l}-0.309 * \\
(0.055) \\
{[-0.00343]^{*}}\end{array}$ & $\begin{array}{l}-0.101 * \\
(0.021) \\
{[-0.00117]^{*}}\end{array}$ & $\begin{array}{l}-0.263^{*} \\
(0.015) \\
{[-0.00366]^{*}}\end{array}$ & $\begin{array}{l}-0.046 * \\
(0.006) \\
{[-0.00054]^{*}}\end{array}$ \\
\hline
\end{tabular}




\begin{tabular}{|c|c|c|c|c|c|c|}
\hline $\begin{array}{l}\text { Log Employment } \\
\text { Variability }\end{array}$ & $\begin{array}{l}0.077^{*} \\
(0.010) \\
{[0.00083]^{*}}\end{array}$ & $\begin{array}{l}0.071^{*} \\
(0.006) \\
{[0.00178]^{*}}\end{array}$ & $\begin{array}{l}0.055^{*} \\
(0.018) \\
{[0.00043]^{*}}\end{array}$ & $\begin{array}{l}0.042^{*} \\
(0.009) \\
{[0.00097]^{*}}\end{array}$ & $\begin{array}{l}0.122^{*} \\
(0.006) \\
{[0.00166]^{*}}\end{array}$ & $\begin{array}{l}0.069^{*} \\
(0.004) \\
{[0.00179]^{*}}\end{array}$ \\
\hline Industry Growth & $\begin{array}{l}0.027 \\
(0.072) \\
{[0.00111]^{*}}\end{array}$ & $\begin{array}{l}-0.113^{*} \\
(0.041) \\
{[-0.00481]^{*}}\end{array}$ & $\begin{array}{l}-0.001 \\
(0.098) \\
{[-0.00005]}\end{array}$ & $\begin{array}{l}-0.007 \\
(0.066) \\
{[-0.00035]^{\wedge}}\end{array}$ & $\begin{array}{l}0.064^{+} \\
(0.037) \\
{[0.00424]^{*}}\end{array}$ & $\begin{array}{l}-0.040 \\
(0.027) \\
{[-0.00163]^{*}}\end{array}$ \\
\hline $\begin{array}{l}\text { County Sector } \\
\text { Growth }\end{array}$ & $\begin{array}{l}-0.050 \\
(0.047) \\
{[-0.00204]^{*}}\end{array}$ & $\begin{array}{l}-0.032 \\
(0.030) \\
{[-0.00141]^{*}}\end{array}$ & $\begin{array}{l}0.029 \\
(0.044) \\
{[0.00181]^{*}}\end{array}$ & $\begin{array}{l}-0.067^{+} \\
(0.037) \\
{[-0.00342]^{*}}\end{array}$ & $\begin{array}{l}0.025 \\
(0.019) \\
{[0.00163]^{*}}\end{array}$ & $\begin{array}{l}0.003 \\
(0.018) \\
{[0.00019]^{*}}\end{array}$ \\
\hline $\begin{array}{l}\text { County Population } \\
\text { Growth }\end{array}$ & $\begin{array}{l}1.680 \\
(1.152) \\
{[0.06807]^{*}}\end{array}$ & $\begin{array}{l}0.219 \\
(0.379) \\
{[0.01120]^{*}}\end{array}$ & $\begin{array}{l}4.063^{+} \\
(2.309) \\
{[0.25282]^{*}}\end{array}$ & $\begin{array}{l}-1.372 \\
(0.964) \\
{[-0.06355]^{*}}\end{array}$ & $\begin{array}{l}2.937^{*} \\
(0.634) \\
{[0.19416]^{*}}\end{array}$ & $\begin{array}{l}0.476^{+} \\
(0.272) \\
{[0.02613]^{*}}\end{array}$ \\
\hline $\begin{array}{l}\text { Log Per Capita } \\
\text { Income }\end{array}$ & $\begin{array}{l}0.364^{*} \\
(0.068) \\
{[0.00049]^{*}}\end{array}$ & $\begin{array}{l}0.151^{*} \\
(0.020) \\
{[0.00024]^{*}}\end{array}$ & $\begin{array}{l}0.017 \\
(0.159) \\
{[0.00004]^{*}}\end{array}$ & $\begin{array}{l}0.185^{*} \\
(0.048) \\
{[0.00032]^{*}}\end{array}$ & $\begin{array}{l}0.122^{\wedge} \\
(0.054) \\
{[0.00027]^{*}}\end{array}$ & $\begin{array}{l}0.044^{*} \\
(0.015) \\
{[0.00007]^{*}}\end{array}$ \\
\hline $\begin{array}{l}\text { Free \& Reduced } \\
\text { Lunch }\end{array}$ & $\begin{array}{l}0.283^{\wedge} \\
(0.136) \\
{[0.01145]^{*}}\end{array}$ & $\begin{array}{l}0.049 \\
(0.039) \\
{[0.00240]^{*}}\end{array}$ & $\begin{array}{l}0.011 \\
(0.243) \\
{[0.00067]}\end{array}$ & $\begin{array}{l}-0.099 \\
(0.091) \\
{[-0.00516]^{*}}\end{array}$ & $\begin{array}{l}-0.155^{\wedge} \\
(0.071) \\
{[-0.01026]^{*}}\end{array}$ & $\begin{array}{l}0.039 \\
(0.027) \\
{[0.00145]^{*}}\end{array}$ \\
\hline $\begin{array}{l}\text { Log Population } \\
\text { Density } \\
(P O P D E N)\end{array}$ & & & $\begin{array}{l}0.103^{*} \\
(0.041) \\
{[0.01710]^{*}}\end{array}$ & & $\begin{array}{l}0.061^{*} \\
(0.013) \\
{[0.01089]^{*}}\end{array}$ & \\
\hline $\begin{array}{l}\text { Hispanic Enrollment } \\
(\text { HISPENROL) }\end{array}$ & $\begin{array}{l}2.241^{*} \\
(0.401) \\
{[0.09079]^{*}}\end{array}$ & & $\begin{array}{l}1.183 \\
(1.252) \\
{[0.07362]^{*}}\end{array}$ & & $\begin{array}{l}0.883^{*} \\
(0.241) \\
{[0.05835]^{*}}\end{array}$ & \\
\hline $\begin{array}{l}\text { County UNDOC } \\
\left(C S \_U N D O C\right)\end{array}$ & $\begin{array}{l}1.585^{*} \\
(0.596) \\
{[0.06421]^{*}}\end{array}$ & & $\begin{array}{l}-1.793^{*} \\
(0.596) \\
{[-0.11159]^{*}}\end{array}$ & & $\begin{array}{l}1.605^{*} \\
(0.372) \\
{[0.10613]^{*}}\end{array}$ & \\
\hline$\rho$ & \multicolumn{2}{|c|}{0.000} & \multicolumn{2}{|c|}{0.000} & \multicolumn{2}{|c|}{0.000} \\
\hline Firms & \multicolumn{2}{|c|}{22,048} & \multirow{2}{*}{\multicolumn{2}{|c|}{$\begin{array}{c}4,083 \\
69569\end{array}$}} & \multirow{2}{*}{\multicolumn{2}{|c|}{46,853}} \\
\hline Observations & \multicolumn{2}{|c|}{417,437} & & & & \\
\hline
\end{tabular}

Panel (d): Education \& Health, Leisure \& Hospitality, Other Services

\begin{tabular}{|l|l|l|l|l|l|l|}
\hline & \multicolumn{2}{|c|}{ Education \& Health } & \multicolumn{2}{c|}{ Leisure \& Hospitality } & \multicolumn{2}{c|}{ Other Services } \\
\hline Regressors & $\mathrm{P}(U N D O C=1)$ & $\mathrm{P}($ Exit=1) & $\mathrm{P}($ UNDOC=1) & $\mathrm{P}($ Exit=1) & $\mathrm{P}($ UNDOC=1) & $\mathrm{P}($ Exit=1) \\
\hline UNDOC & & -0.051 & & $-0.122^{*}$ & & $-0.346^{*}$ \\
& & $(0.034)$ & & $(0.017)$ & & $(0.104)$ \\
& & {$[-0.00156]^{*}$} & & {$[-0.00524]^{*}$} & & {$[-0.01342]^{*}$} \\
\hline IndUNDOC & 1.322 & $4.131^{*}$ & $6.933^{*}$ & 0.045 & $13.048^{*}$ & 1.007 \\
& $(1.052)$ & $(0.782)$ & $(0.760)$ & $(0.501)$ & $(1.459)$ & $(0.913)$ \\
& {$[0.08641]^{*}$} & {$[0.03680]^{*}$} & {$[0.59774]^{*}$} & {$[0.01920]^{*}$} & {$[0.27463]^{*}$} & {$[0.02377]^{*}$} \\
\hline BroadMarket & $-0.396^{*}$ & $0.430^{*}$ & 0.235 & $0.217^{+}$ & -0.189 & $0.372^{*}$ \\
& $(0.142)$ & $(0.078)$ & $(0.239)$ & $(0.130)$ & $(0.165)$ & $(0.058)$ \\
& {$[-0.02018]^{*}$} & {$[0.00919]^{*}$} & {$[-0.21899]^{*}$} & {$[0.00279]^{*}$} & {$[-0.05011]^{*}$} & {$[0.01647]^{*}$} \\
\hline Broad*INDUNDOC & 0.428 & $-4.644^{*}$ & $-6.836^{*}$ & -0.033 & $-12.188^{*}$ & -1.149 \\
& $(1.377)$ & $(1.041)$ & $(1.189)$ & $(0.798)$ & $(2.110)$ & $(1.317)$ \\
\hline 1 Employee & $-1.378^{*}$ & $1.148^{*}$ & $-2.121^{*}$ & $0.697^{*}$ & $-1.366^{*}$ & $0.946^{*}$ \\
& $(0.087)$ & $(0.085)$ & $(0.086)$ & $(0.074)$ & $(0.180)$ & $(0.192)$ \\
& {$[-0.03583]^{*}$} & {$[0.09975]^{*}$} & {$[-0.20966]^{*}$} & {$[0.05853]^{*}$} & {$[-0.04906]^{*}$} & {$[0.07194]^{*}$} \\
\hline 2 Employees & $-1.079^{*}$ & $0.995^{*}$ & $-1.867 *$ & $0.583^{*}$ & $-0.950^{*}$ & $0.792^{*}$ \\
& $(0.095)$ & $(0.085)$ & $(0.082)$ & $(0.073)$ & $(0.179)$ & $(0.192)$ \\
& {$[-0.03275]^{*}$} & {$[0.07974]^{*}$} & {$[-0.20781]^{*}$} & {$[0.04423]^{*}$} & {$[-0.03482]^{*}$} & {$[0.07452]^{*}$} \\
\hline 3-10 Employees & $-0.892^{*}$ & $0.754^{*}$ & $-1.259^{*}$ & $0.373^{*}$ & $-0.621^{*}$ & $0.631^{*}$ \\
& $(0.079)$ & $(0.082)$ & $(0.074)$ & $(0.070)$ & $(0.174)$ & $(0.190)$ \\
& {$[-0.05486]^{*}$} & {$[0.03469]^{*}$} & {$[-0.24769]^{*}$} & {$[0.01975]^{*}$} & {$[-0.03670]^{*}$} & {$[0.04760]^{*}$} \\
\hline
\end{tabular}




\begin{tabular}{|c|c|c|c|c|c|c|}
\hline 11-100 Employees & $\begin{array}{l}-0.610^{*} \\
(0.067) \\
{[-0.03461]^{*}}\end{array}$ & $\begin{array}{l}0.539 * \\
(0.077) \\
{[0.02691]^{*}}\end{array}$ & $\begin{array}{l}-0.733^{*} \\
(0.067) \\
{[-0.13981]^{*}}\end{array}$ & $\begin{array}{l}0.199 * \\
(0.065) \\
{[0.01001]^{*}}\end{array}$ & $\begin{array}{l}-0.299^{+} \\
(0.165) \\
{[-0.01421]^{*}}\end{array}$ & $\begin{array}{l}0.328^{+} \\
(0.186) \\
{[0.02308]^{*}} \\
\end{array}$ \\
\hline 101-250 Employees & $\begin{array}{l}-0.338^{*} \\
(0.062) \\
{[-0.02295]^{*}}\end{array}$ & $\begin{array}{l}0.372^{*} \\
(0.074) \\
{[0.01868]^{*}}\end{array}$ & $\begin{array}{l}-0.266^{*} \\
(0.065) \\
{[-0.05451]^{*}}\end{array}$ & $\begin{array}{l}0.140^{\wedge} \\
(0.064) \\
{[0.00697]^{*}}\end{array}$ & $\begin{array}{l}-0.067 \\
(0.159) \\
{[-0.00358]^{*}}\end{array}$ & $\begin{array}{l}-0.017 \\
(0.211) \\
{[-0.00099]^{*}}\end{array}$ \\
\hline Wage/1000 & $\begin{array}{l}-0.002 \\
(0.002) \\
{[-0.00012]^{*}}\end{array}$ & $\begin{array}{l}-0.002 * \\
(0.001) \\
{[-0.00007]^{*}}\end{array}$ & $\begin{array}{l}-0.042^{*} \\
(0.006) \\
{[-0.00820]^{*}}\end{array}$ & $\begin{array}{l}-0.004^{+} \\
(0.002) \\
{[-0.00043]^{*}}\end{array}$ & $\begin{array}{l}-0.017^{+} \\
(0.010) \\
{[-0.00099]^{*}}\end{array}$ & $\begin{array}{l}-0.011^{*} \\
(0.002) \\
{[-0.00054]^{*}}\end{array}$ \\
\hline Wage Squared/10000 & $\begin{array}{l}0.001 \\
(0.001)\end{array}$ & $\begin{array}{l}0.001 \\
(0.000)\end{array}$ & $\begin{array}{l}0.018^{*} \\
(0.003)\end{array}$ & $\begin{array}{l}0.004 * \\
(0.002)\end{array}$ & $\begin{array}{l}-0.019 \\
(0.039)\end{array}$ & $\begin{array}{l}0.010^{*} \\
(0.002)\end{array}$ \\
\hline $\begin{array}{l}\text { Proportion of } \\
\text { Documented Workers } \\
\text { Part-time }\end{array}$ & $\begin{array}{l}0.173^{*} \\
(0.046) \\
{[0.00939]^{*}}\end{array}$ & $\begin{array}{l}0.155^{*} \\
(0.019) \\
{[0.00517]^{*}}\end{array}$ & $\begin{array}{l}-0.918^{*} \\
(0.047) \\
{[-0.18312]^{*}}\end{array}$ & $\begin{array}{l}0.168^{*} \\
(0.023) \\
{[0.00190]^{*}}\end{array}$ & $\begin{array}{l}-0.071 \\
(0.049) \\
{[-0.00370]^{*}}\end{array}$ & $\begin{array}{l}0.020 \\
(0.013) \\
{[0.00091]^{*}}\end{array}$ \\
\hline Age & $\begin{array}{l}0.015^{*} \\
(0.003) \\
{[0.00019]^{*}}\end{array}$ & $\begin{array}{l}-0.013^{*} \\
(0.002) \\
{[-0.00021]^{*}}\end{array}$ & $\begin{array}{l}0.014^{*} \\
(0.002) \\
{[-0.00031]^{*}}\end{array}$ & $\begin{array}{l}-0.013^{*} \\
(0.002) \\
{[0.04493]^{*}}\end{array}$ & $\begin{array}{l}0.009^{*} \\
(0.003) \\
{[0.00015]^{*}}\end{array}$ & $\begin{array}{l}-0.014^{*} \\
(0.001) \\
{[-0.00036]^{*}}\end{array}$ \\
\hline Age Squared/100 & $\begin{array}{l}-0.017 * \\
(0.004)\end{array}$ & $\begin{array}{l}0.012^{*} \\
(0.002)\end{array}$ & $\begin{array}{l}-0.021^{*} \\
(0.003)\end{array}$ & $\begin{array}{l}0.012^{*} \\
(0.003)\end{array}$ & $\begin{array}{l}-0.009^{\wedge} \\
(0.004)\end{array}$ & $\begin{array}{l}0.013^{*} \\
(0.002) \\
\end{array}$ \\
\hline Multi-establishment & $\begin{array}{l}0.105^{\wedge} \\
(0.051) \\
{[0.00909]^{*}}\end{array}$ & $\begin{array}{l}0.039 \\
(0.047) \\
{[0.00143]^{*}}\end{array}$ & $\begin{array}{l}0.204^{*} \\
(0.048) \\
{[0.04493]^{*}}\end{array}$ & $\begin{array}{l}-0.123^{*} \\
(0.043) \\
{[-0.00477]^{*}}\end{array}$ & $\begin{array}{l}-0.010 \\
(0.093) \\
{[-0.00053]^{\wedge}}\end{array}$ & $\begin{array}{l}-0.212^{\wedge} \\
(0.101) \\
{[-0.01026]^{*}}\end{array}$ \\
\hline $\begin{array}{l}\text { Employment } \\
\text { Churning }\end{array}$ & $\begin{array}{l}0.005^{*} \\
(0.002) \\
{[0.00028]^{*}}\end{array}$ & $\begin{array}{l}-0.008 \\
(0.005) \\
{[-0.00024]^{*}}\end{array}$ & $\begin{array}{l}0.014^{*} \\
(0.003) \\
{[0.00286]^{*}}\end{array}$ & $\begin{array}{l}-0.005^{\wedge} \\
(0.002) \\
{[-0.00014]^{*}}\end{array}$ & $\begin{array}{l}0.020^{*} \\
(0.005) \\
{[0.00106]^{*}}\end{array}$ & $\begin{array}{l}0.001 \\
(0.002) \\
{[0.00007]^{*}}\end{array}$ \\
\hline Log Tenure & $\begin{array}{l}-0.203^{*} \\
(0.022) \\
{[-0.00176]^{*}}\end{array}$ & $\begin{array}{l}-0.006 \\
(0.010) \\
{[-0.00008]^{*}}\end{array}$ & $\begin{array}{l}-0.292^{*} \\
(0.018) \\
{[-0.01308]^{*}}\end{array}$ & $\begin{array}{l}-0.069 * \\
(0.010) \\
{[-0.00128]^{*}}\end{array}$ & $\begin{array}{l}-0.251^{*} \\
(0.019) \\
{[-0.00242]^{*}}\end{array}$ & $\begin{array}{l}-0.061^{*} \\
(0.006) \\
{[-0.00069]^{*}}\end{array}$ \\
\hline $\begin{array}{l}\text { Log Employment } \\
\text { Variability }\end{array}$ & $\begin{array}{l}0.094^{*} \\
(0.008) \\
{[0.00100]^{*}}\end{array}$ & $\begin{array}{l}0.053^{*} \\
(0.006) \\
{[0.00088]^{*}}\end{array}$ & $\begin{array}{l}0.144 * \\
(0.007) \\
{[0.00442]^{*}}\end{array}$ & $\begin{array}{l}0.037^{*} \\
(0.005) \\
{[0.00073]^{*}}\end{array}$ & $\begin{array}{l}0.152^{*} \\
(0.012) \\
{[0.00250]^{*}}\end{array}$ & $\begin{array}{l}0.084^{*} \\
(0.008) \\
{[0.00328]^{*}}\end{array}$ \\
\hline Industry Growth & $\begin{array}{l}-0.019 \\
(0.065) \\
{[-0.00103]^{*}}\end{array}$ & $\begin{array}{l}0.011 \\
(0.060) \\
{[0.00033]^{*}}\end{array}$ & $\begin{array}{l}-0.006 \\
(0.063) \\
{[-0.00115]^{*}}\end{array}$ & $\begin{array}{l}-0.009 \\
(0.059) \\
{[-0.00042]^{*}}\end{array}$ & $\begin{array}{l}-0.232 * \\
(0.056) \\
{[-0.00967]^{*}}\end{array}$ & $\begin{array}{l}-0.177 * \\
(0.045) \\
{[0.00364]^{*}}\end{array}$ \\
\hline $\begin{array}{l}\text { County Sector } \\
\text { Growth }\end{array}$ & $\begin{array}{l}-0.019 \\
(0.036) \\
{[-0.00105]^{*}}\end{array}$ & $\begin{array}{l}-0.061^{+} \\
(0.034) \\
{[-0.00199]^{*}}\end{array}$ & $\begin{array}{l}0.039^{+} \\
(0.021) \\
{[0.00768]^{*}}\end{array}$ & $\begin{array}{l}-0.019 \\
(0.029) \\
{[-0.00063]^{*}}\end{array}$ & $\begin{array}{l}0.070 \\
(0.055) \\
{[0.00364]^{*}}\end{array}$ & $\begin{array}{l}-0.049 \\
(0.037) \\
{[-0.00243]^{*}}\end{array}$ \\
\hline $\begin{array}{l}\text { County Population } \\
\text { Growth }\end{array}$ & $\begin{array}{l}2.954^{*} \\
(0.756) \\
{[0.16007]^{*}}\end{array}$ & $\begin{array}{l}-1.113^{*} \\
(0.385) \\
{[-0.03226]^{*}}\end{array}$ & $\begin{array}{l}3.909^{*} \\
(0.640) \\
{[0.77939]^{*}}\end{array}$ & $\begin{array}{l}0.143 \\
(0.401) \\
{[0.03009]^{*}}\end{array}$ & $\begin{array}{l}1.579^{+} \\
(0.881) \\
{[0.08231]^{*}}\end{array}$ & $\begin{array}{l}0.538^{+} \\
(0.320) \\
{[0.03096]^{*}}\end{array}$ \\
\hline $\begin{array}{l}\text { Log Per Capita } \\
\text { Income }\end{array}$ & $\begin{array}{l}-0.016 \\
(0.059) \\
{[-0.00003]^{*}}\end{array}$ & $\begin{array}{l}0.047^{\wedge} \\
(0.020) \\
{[0.00006]^{*}}\end{array}$ & $\begin{array}{l}0.434^{*} \\
(0.060) \\
{[0.00305]^{*}}\end{array}$ & $\begin{array}{l}0.133^{*} \\
(0.022) \\
{[0.00031]^{*}}\end{array}$ & $\begin{array}{l}0.330^{*} \\
(0.074) \\
{[0.00059]^{*}}\end{array}$ & $\begin{array}{l}-0.066^{*} \\
(0.017) \\
{[-0.00011]^{*}}\end{array}$ \\
\hline $\begin{array}{l}\text { Free \& Reduced } \\
\text { Lunch }\end{array}$ & $\begin{array}{l}0.071 \\
(0.080) \\
{[0.00383]^{*}}\end{array}$ & $\begin{array}{l}0.030 \\
(0.041) \\
{[0.00104]^{*}}\end{array}$ & $\begin{array}{l}-0.181^{\wedge} \\
(0.075) \\
{[-0.03608]^{*}}\end{array}$ & $\begin{array}{l}0.022 \\
(0.043) \\
{[-0.00010]}\end{array}$ & $\begin{array}{l}0.044 \\
(0.109) \\
{[0.00231]^{*}}\end{array}$ & $\begin{array}{l}-0.058^{+} \\
(0.034) \\
{[-0.00295]^{*}}\end{array}$ \\
\hline $\begin{array}{l}\text { Log Population } \\
\text { Density } \\
(P O P D E N)\end{array}$ & $\begin{array}{l}0.100 * \\
(0.013) \\
{[0.02109]^{*}}\end{array}$ & & $\begin{array}{l}0.079 * \\
(0.012) \\
{[0.05721]^{*}}\end{array}$ & & $\begin{array}{l}0.068^{*} \\
(0.019) \\
{[0.00937]^{*}}\end{array}$ & \\
\hline $\begin{array}{l}\text { Hispanic Enrollment } \\
(H I S P E N R O L)\end{array}$ & & & $\begin{array}{l}1.770 * \\
(0.256) \\
{[0.35291]^{*}}\end{array}$ & & $\begin{array}{l}0.744^{\wedge} \\
(0.320) \\
{[0.03878]^{*}}\end{array}$ & \\
\hline $\begin{array}{l}\text { County UNDOC } \\
\left(C S \_U N D O C\right)\end{array}$ & $\begin{array}{l}0.226 \\
(0.471) \\
{[0.01225]^{*}}\end{array}$ & & $\begin{array}{l}0.749 * \\
(0.154) \\
{[0.14941]^{*}}\end{array}$ & & $\begin{array}{l}3.851^{*} \\
(0.632) \\
{[0.20078]^{*}}\end{array}$ & \\
\hline
\end{tabular}




\begin{tabular}{|l|c|c|c|}
\hline$\rho$ & 0.000 & 0.000 & $0.125^{\wedge}$ \\
\hline Firms & & & $(0.053)$ \\
\hline Observations & 22,686 & 18,789 & 27,028 \\
\hline
\end{tabular}

Notes: Standard errors (corrected for firm clustering) are shown in parentheses. Marginal effects are in brackets. Significance

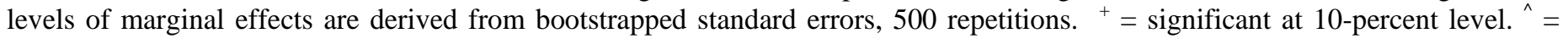
significant at 5-percent level. * = significant at 1-percent level. 


\section{References}

Akerlof, George A., and Janet L. Yellen, 1990. "The Fair Wage-Effort Hypothesis and Unemployment." Quarterly Journal of Economics 105, no. 2, (May): 255-83.

Barth, Erling, and Harald Dale-Olsen. 1999. "Monopsonistic Discrimination and the Genderwage Gap," Working Paper no. W7197, NBER, Cambridge, MA.

Baslevent, Cem, Kustepe Sisli, and Fatma El-Hamidi. 2007. "Preferences for Early Retirement among Older Government Employees in Egypt." Mimeo, Department of Economics, Istanbul Bilgi University.

Becker, Gary S. 1971. The Economics of Discrimination. Second Edition. Chicago: University of Chicago Press.

Bhaskar, V., Alan Manning, and Ted To. 2002. "Oligopsony and Monopsonistic Competition in Labor Markets." Journal of Economic Perspectives 16, no. 2, (Spring): 155-74.

Borjas, George J., and Lawrence F. Katz. 2005. “The Evolution of the Mexican-Born Workforce in the United States.” Working Paper no. 11281, NBER, Cambridge, MA.

Bovbjerg, Barbara D. 2006. Social Security Numbers: Coordinated Approach to SSN Data Could Help Reduce Unauthorized Work, Testimony before the Subcommittees on Social Security and on Oversight, Committee on Ways and Means, House of Representatives, GAO-06-458T, http://www.gao.gov/new.items/d06458t.pdf, (accessed 15 December 2008).

Cave, Damien. 2008. “States Take New Tack on Illegal Immigration.” New York Times, June 9, (accessed 9 June 2008).

Champlin, Dell, and Eric Hake. 2006. "Immigration as Industrial Strategy in American Meatpacking." Journal of Political Economy 18, no.1, (January): 49-69.

Committee on Ways and Means, House of Representatives. 2004. Greenbook, WMCP 108-6, Section 4, (April).

Cortes, Patricia. 2008. "The Effect of Low-skilled Immigration on U.S. Prices: Evidence from CPI Data." Journal of Political Economy 116, no. 3: 381-422.

Davis, Steven J., and John C. Haltiwanger.1992. "Gross Job Creation, Gross Job Destruction, and Employment Reallocation." Quarterly Journal of Economics 107, no. 3, (August): 819-63.

Disney, Richard, Jonathan Haskel, and Ylva Heden. 2003. "Entry, Exit and Establishment Survival in UK Manufacturing." The Journal of Industrial Economics 51, no. 1 (March): 91-112. 
Duncan, Otis D. and Beverly Duncan. 1955. "A Methodological Analysis of Segregation Indexes." American Sociological Review 20, (April): 210-17.

Dunne, Timothy, Mark J. Roberts, and Larry Samuelson. 1989. "The Growth and Failure of U.S. Manufacturing Plants." The Quarterly Journal of Economics 104, no. 4, (November): 671-98.

Earle, John S. and Klara Sabirianova Peter. forthcoming. "Complementary and Custom in Wage Contract Violation." Review of Economics and Statistics.

Ericson, Richard and Ariel Pakes. 1995. "Markov-Perfect Industry Dynamics: A Framework for Empirical Work." Review of Economic Studies 62, no. 1 (January): 53-82.

Fortuny, Karina, Randy Capps, and Jeffrey S. Passel. 2007. "The Characteristics of Unauthorized Immigrants in California, Los Angeles County, and the United States," Mimeo. Washington, D.C.: The Urban Institute (March).

Gibbons, Margaret. 2008. "Labor Union Criticizes the Handling of Immigrants." TimesHerald.com (6 August), $<$ http://www.timesherald.com/site/printerFriendly.cfm?brd=1672\&dept_id=33380\&news id=19894880 > , (accessed 6 August 2008).

Greenhouse, Steven. 1999. "U.S. to Expand Anti-discrimination Rights for Illegal Immigrants Working in This Country." nytimes.com (28 October) $<$ http://query.nytimes.com/gst/fullpage.html?res=9C00E7DE1138F93BA15753C1A96F958260\&s

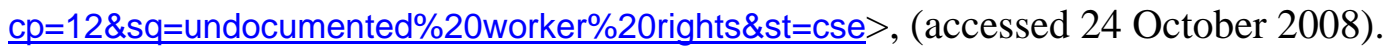

Greene, William H. 2008. "Gender Economics Courses in Liberal Arts Colleges: Further Results." Research in Economic Education 29, no. 4 (Fall): 291-300.

Greene, William H. 1996. "Marginal Effects in the Bivariate Probit Model." Mimeo, Department of Economics, New York University, EC-96-11, (June).

Hanson, Gordon H. 2066. "Illegal Migration from Mexico to the United States.” Journal of Economic Literature 44, no. 4, (December): 869-924.

Hirsch, Boris, Thorsten Schank, and Claus Schnabel. 2006. "Gender Differences in Labor Supply to Monopsonistic Firms: An Empirical Analysis Using Linked Employer-Employee Data from Germany." Friedrich-alexander-Universitat Erlangen-Nurnberg Discussion Papers No. 47, (November).

Hoefer, Michael, Nancy Rytina, and Christopher Campbell. 2007. "Estimates of the Unauthorized Immigrant Population Residing in the United States: January 2006," Population Estimates. Washington, D.C.: US Department of Homeland Security, Office of Immigration Statistics, (August). 
Hotchkiss, Julie L., and Myriam Quispe-Agnoli. 2008. “The Labor Market Experience and Impact of Undocumented Workers.” Federal Reserve Bank of Atlanta Working Paper 2008-7(c), (February).

Huse, James G. 2002. Congressional Response Report: Status of the Social Security Administration's Earnings Suspense File A-03-03-23038 (November) http://www.ssa.gov/oig/ADOBEPDF/A-03-03-23038.pdf, (accessed 11 December 2008).

Johnson, Mary. 2007. "The Growing Cost of Illegal Immigrants to Social Security: Unprecedented Growth in Social Security's 'Earnings Suspense File." Mimeo (March) $<$ http://www.tscl.org/NewContent/102880.asp> (accessed 11 December 2008)

Jovanovic, Boyan. 1982. “Selection and Evolution of Industry.” Econometrica 50, no. 3 (May): 649-670.

Manski, Charles F. 1992. "Identification of Endogenous Social Effects: The Reflection Problem." Review of Economic Studies 60, no. 3 (July): 531-42.

Monfardini, Chirara and Rosalba Radice. 2008. "Testing Exogeneity in the Bivariate Probit Model: A Monte Carlo Study." Oxford Bulletin of Economics and Statistics 70, no. 2: 271-82.

Morales, Rebecca. 1983. “Transitional Labor: Undocumented Workers in the Los Angeles Automobile Industry.” International Migration Review 17, no. 4 (Winter): 570-596. .

Perotin, Virginie, Andrew Robinson, and Joanne Loundes. 2003. “Equal Opportunities Practices and Enterprise Performance: A Comparative Investigation on Australian and British Data.” International Labour Review 142 no. 4 (December): 471-505.

Preston, Julia. 2007. "Short on Labor, Farmers in U.S. Shift to Mexico." nytimes.com, (5 September), <http://www.nytimes.com/2007/09/05/us/05export.htm>, (accessed 17 October 2008).

Robinson, Joan. 1933. The Economics of Imperfect Competition, Macmillan: London.

Semple, Kirk. 2008. "With Economy, Day Laborer Jobs Dwindle." nytimes.com (20 October), $<$ http://www.nytimes.com/2008/10/20/nyregion/20laborers.html?partner=rssnyt>, (accessed 20 October 2008).

Stark, Oded. 2007. "Work Effort, Moderation in Expulsion, and Illegal Migration." Review of Development Economics 11 no. 4 (February): 585-90. 
Subcomittee on Workforce Protections of the Committee on Education and the Workforce, U.S. House of Representatives, Field Hearing in Gainesville, Georgia. 2006. "Immigration: Economic Impact on American Workers and their Wages.” Washington: U.S.

Government Printing Office, Serial No. 109-52, (August 14)

<http://bulk.resource.org/gpo.gov/hearings/109h/29475.txt>, (accessed 30 July 2008).

U.S. Department of Housing and Urban Development. 1990. "Disclosure and Verification of Social Security Numbers (SSNs) for the Section 235 Program." Mortgagee Letter 90-39, (9 November),

http://209.85.165.104/search?q=cache:5VRIgv1oFQYJ:www.fha.gov/reference/ml1990/9

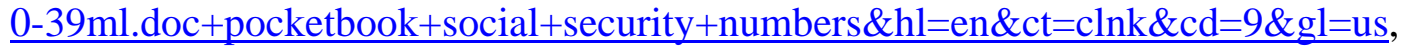
(accessed 20 September 2007).

U.S. Department of Labor, Employment and Training Administration. 2008. "Comparison of State Unemployment Laws", http://workforcesecurity.doleta.gov/unemploy/uilawcompar/2008/comparison2008.asp, (accessed 10 December 2008).

Wilde, Joachim. 2000. "Identification of Multiple Equation Probit Models with Endogenous Dummy Regressors." Economics Letters 69, no. 3 (December): 309-12.

Winter-Ebmer, Rudolf and Josef Zweimüller. 1999. "Intra-firm Wage Dispersion and Firm Performance." Kyklos 52 no. 4 (May): 555-72. 
Appendix A: Definitions of sectors based on NAICS classifications.

Table A1: Definitions of sectors based on 2-digit NAICS classifications.

\begin{tabular}{ll}
\hline Sector & Included \\
& 2-digit \\
& NAICS \\
\hline Agriculture and Natural Resources & 11,21 \\
Construction & 23 \\
Manufacturing & $31-33$ \\
Transportation and Utilities & $22,48-49$ \\
Wholesale Trade & 42 \\
Retail Trade & $44-45$ \\
Financial Activities & $52-53$ \\
Information & 51 \\
Professional and Business Services (includes temporary services) & $54-56$ \\
Education and Health Services & $61-62$ \\
Leisure and Hospitality & $71-72$ \\
Other Services & 81 \\
(includes private household, laundry, and repair and maintenance services) & \\
\hline
\end{tabular}

